\title{
Khảo sát hiệu quả xử lý nước thải chăn nuôi heo sau bể biogas bằng công nghệ lọc sinh học kết hợp bãi lọc thực vật
}

\section{Efficiency investigation of livestock wastewater after biogas treatment by biofilter technology combined with constructed wetlands}

\author{
Phan Nguyễn Tường ${ }^{1}$, Hoàng Thanh Trang ${ }^{1}$, Cao Thị Mỹ Tiên ${ }^{1}$, Trần Thái Hà ${ }^{*}$ \\ ${ }^{1}$ Khoa Công nghệ Sinh học, Trường Đại học Mở Thành phố Hồ Chí Minh, Việt Nam \\ *Tác giả liên hệ, Email: ha.tt@ou.edu.vn
}

\begin{tabular}{ll}
\hline THÔNG TIN & TÓM TĂT \\
\hline
\end{tabular}

DOI: $10.46223 / \mathrm{HCMCOUJS.}$ tech.vi.15.1.1019.2020

Ngày nhận: 15/01/2020

Ngày nhận lại: 24/04/2020

Duyệt đăng: 20/05/2020

Tù khóa:

bể lọc sinh học, màng sinh học, bể lọc thực vật, hiệu quả xử lý, nước thải chăn nuôi
Nghiên cứu được thực hiện nhằm đánh giá khả năng xử lý nước thải chăn nuôi heo sau bể biogas từ một cơ sở chăn nuôi hộ gia đình tại tỉnh Bình Dương bằng công nghệ lọc sinh học kết hợp bãi lọc thực vật. Hiệu quả xử lý nước thải được đánh giá thông qua bốn chỉ tiêu chất lượng nước thải: Tổng rắn lơ lửng (TSS), nhu cầu oxi sinh hóa (BOD), amoni $(\mathrm{NH}+4)$, độ đục. Hiệu quả ghi nhận được tốt nhất qua nghiên cứu tại bể lọc sinh học là: TSS 36,96\%, BOD 34,69\%, Amoni 36,07\% và độ đục $34,77 \%$. Hiệu quả thu được tốt nhất qua nghiên cứu tại bể lọc thực vật là: tại bể lọc thực vật A (wetland A) với BOD 45 $\%$, Amoni 70\%, TSS 80\%, độ đục $50 \%$ và tại bể lọc thực vật $\mathrm{C}$ (wetland C) với BOD là $40 \%$, Amoni là 50\%, TSS là 70\%, độ đục là $48 \%$. Kết quả thực nghiệm cho thấy công nghệ lọc sinh học kết hợp bể lọc thực vật, làm giảm nồng độ chất ô nhiễm BOD, TSS, Amoni... một cách hiệu quả. Tuy nhiên, trong nghiên cứu này thì sự kết hợp giữa việc xử lý bằng bể lọc sinh học và bể lọc thực vật vẫn chưa đảm bảo nước thải sau xử lý đạt giá trị cho phép xả thải quy định trong QCVN 62-MT: 2016/BTNMT. Kết quả nghiên cứu cho thấy sự kết hợp giữa bể lọc sinh học và bể lọc thực vật là rất tiềm năng trong việc áp dụng để xử lý nước thải chăn nuôi sau biogas.

\section{ABSTRACT}

The research was conducted to assess the ability to treat livestock wastewater after biogas treatment from one small livestockhouse of Binh Duong province by biofilter technology combined with constructed wetlandsThe treatment capacity of pilot model was studied with four different parameters including: TSS, BOD, ammonium, turbidity. The best treatment capacity was observed are: TSS 36,96\%, BOD 34,69\%, ammonium $36,07 \%$ and turbidity $34,77 \%$. The best results obtained through research at the wetland are: at the wetland A 


\section{Keywords:}

biofilter, biofilm, constructed wetlands, treatment capacity, livestock wastewater about BOD 45\%, Ammonium 70\%, TSS 80\%, and turbidity $50 \%$ and at the wetland $\mathrm{C}$ about BOD is $40 \%$, ammonium $50 \%$, TSS $70 \%$, and turbidity $48 \%$. Although the wastewater is treated by biofilter and continues to be treated by wetland, the treated wastewater still has values higher than the allowable values specified in QCVN 62-MT: 2016/BTNMT. Experimental results show that the biofilter technology combined with constructed wetlands, reducing the concentration of BOD, TSS, ammonium... effectively.

\section{1. Đặt vấn đề}

Theo thống kê của Bộ Nông nghiệp và Phát triển nông thôn (BNN\&PTNT) về chăn nuôi, cả nước hiện có khoảng 29 triệu con lợn. Mỗi năm khối lượng nguồn thải từ chăn nuôi ra môi trường là khoảng 84,5 triệu tấn/năm, trong đó, chỉ khoảng $20 \%$ được sử dụng hiệu quả (làm khí sinh học, ủ phân, nuôi trùn, cho cá ăn,...), còn lại $80 \%$ lượng chất thải chăn nuôi đã bị lãng phí và phần lớn thải ra môi trường gây ô nhiễm ( $\mathrm{T}$. $\mathrm{H}$. Nguyen, 2017). Nước thải chăn nuôi heo là nguồn nước thải có hàm lượng chất ô nhiễm cao (chất hữu cơ, chất dinh dưỡng, chất rắn lơ lửng), sẽ gây ô nhiễm môi trường nếu không xử lý tốt (Choi \& Eum, 2002; Le, Le, \& Nguyen, 2012).

Tính đến năm 2018, theo thống kê chăn nuôi, tại Bình Dương tổng đàn heo có 583.928 con, 117 trang trại, trong đó có các công ty đầu tư nuôi heo thịt và heo giống năng suất cao (Công ty $\mathrm{CP}, \mathrm{ADECO}, \mathrm{CJ}$ Vina, Thanh Bình, Japfa,...) và các trang trại chăn nuôi heo nhỏ lẻ của hộ dân. Tại các trang trại chăn nuôi heo nhỏ lẻ, xử lý nước thải bằng phương pháp hầm tự hoại biogas thường đượ áp dụng vì chi phí thấp.

Nước thải chăn nuôi thường được xử lý bằng dây chuyền công nghệ kết hợp quá trình cơ học, hóa-lý, sinh học (Grady, Daigger, \& Lim, 1999; Luong, 2007; V. P. Nguyen, 2010; Tchobanoglous, Burton, \& Stensel, 2016; Trinh, 2009). Đối với các hộ dân chăn nuôi nhỏ lẻ tại Bình Dương, nước thải chăn nuôi heo thường được gom vào hệ thống hầm Biogas để xử lý. Phương pháp này chủ yếu dựa vào sự hoạt động phân hủy các chất hữu cơ của vi khuẩn trong điều kiện yếm khí. Tuy nhiên nước thải sau Biogas có các thành phần gây ô nhiễm môi trường vẫn còn ở mức cao chưa đạt tiêu chuẩn xả thải ra môi trường. Vì vậy phương pháp sử dụng vi sinh dính bám trong bể lọc sinh học kết hợp bãi lọc thực vật được lựa chọn để khảo sát trong nghiên cứu này vì hệ thống này có nhiều ưu điểm nổi bật như cấu tạo đơn giản, hiệu quả xử lý cao, chi phí xây dựng và vận hành thấp... rất thích hợp áp dụng xử lý nước thải chăn nuôi heo sau xử lý biogas phù hợp với điều kiện các hộ gia đình trên địa bàn tỉnh Bình Dương. Nghiên cứu này tập trung "Khảo sát hiệu quả xử lý nước thải chăn nuôi heo sau bể biogas bằng công nghệ lọc sinh học kết hợp bãi lọc thực vật" nhằm bước đầu đánh giá hiệu quả của việc kết hợp các công nghệ chi phí thấp, công nghệ thân thiện không hóa chất, đáp ứng nhu cầu xử lý nước thải chăn nuôi phù hợp với các tiêu chuẩn xả thải ra môi trường.

\section{Vật liệu và phương pháp nghiên cứu}

\subsection{Nội dung nghiên cúu}

\subsection{1. Đối tuợng nghiên cứu}

Mẫu nước thải chăn nuôi được lấy tại cơ sở chăn nuôi heo của hộ gia đình anh Đào đường Công Chúa Ngọc Hân tổ 01 khu phố 05 thị trấn Phước Vĩnh huyện Phú Giáo, tỉnh Bình 
Dương. Hộ gia đình chăn nuôi khoảng 100 con heo, heo xuất chuồng sẽ được thương lái mua và phục vụ cho các chợ trên địa bàn tỉnh Bình Dương. Nước thải lấy ở hầm chứa nước sau khi được xử lý ở hệ thống Biogas. Mỗi lần lấy 30 lít trong 1 bình nhựa 30 lít, đủ số lượng cho 1 lần chạy mô hình thí nghiệm. Thí nghiệm được thực hiện trong 6 tháng, từ tháng 08/2019 đến tháng 01/2020. Mẫu nước thải được xử lý và phân tích ở phòng Thí nghiệm Hóa - Môi trường, Trường Đại học Mở Thành phố Hồ Chí Minh, cơ sở 3 Bình Dương. Các thông số ô nhiễm chính của nước thải từ cơ sở chăn nuôi heo của hộ gia đình trên huyện Phú Giáo được trình bày trong Bảng 1.

\section{Bảng 1}

Chỉ tiêu chất lượng nước thải chăn nuôi heo sau Biogas của một cơ sở tại Phú Giáo

\begin{tabular}{|c|c|c|c|}
\hline STT & Chỉ tiêu & Đơn vị & Giá trị \\
\hline 1 & $\mathrm{BOD}_{5}$ & $\mathrm{mg} / \mathrm{l}$ & $308-592$ \\
\hline 2 & $\mathrm{TSS}$ & $\mathrm{mg} / 1$ & $290-690$ \\
\hline 3 & $\mathrm{Amoni}\left(\mathrm{NH}_{4}{ }^{+}\right)$ & $\mathrm{mg} / \mathrm{l}$ & $328-514$ \\
\hline 4 & Độ đục & $\mathrm{NTU}$ & $189-375$ \\
\hline
\end{tabular}

Nguồn: Kết quả phân tích dữ liệu của nhóm nghiên cứu

\subsubsection{Nội dung nghiên cúu}

Đối với bể lọc sinh học: vật liệu sử dụng trong nghiên cứu này là giá thể vi sinh dạng bánh xe. Do diện tích tiếp xúc lớn hơn $500 \mathrm{~m}^{2} / \mathrm{m}^{3}$, kích thước $25 \times 10 \mathrm{~mm}$ tạo điều kiện cho vi sinh vật bám dính và thích nghi, trọng lượng nhẹ phù hợp với bể (Hình 1). Bề mặt vật liệu có lổ hổng thích hợp để vi sinh dánh bám và phát triển. Giá thể vi sinh dạng bánh xe được sản xuất bằng nhựa HDPE, độ bền cao. Các khoảng cách giữa các hạt vật liệu tạo đủ khoảng không để vi sinh vật lấy ôxi.

Trong giai đoạn đầu của thí nghiệm thì chế phẩm vi sinh EM-Pro được dùng như mồi vi sinh phát triển. Chế phẩm được mua từ SACOTEC, bao gồm các chủng Saccharomyces sp.: $109 \mathrm{cfu} / \mathrm{ml}$; Lactobacillus sp.: $10^{9} \mathrm{cfu} / \mathrm{ml}$; Bacillus sp.: $10^{9} \mathrm{cfu} / \mathrm{ml}$; Rhodopseudomonas sp.: $10^{8} \mathrm{cfu} / \mathrm{ml}$; Dung dịch chế phẩm có màu vàng nâu nhạt, $\mathrm{pH}$ là 3.5 , mùi thơm nhẹ. 


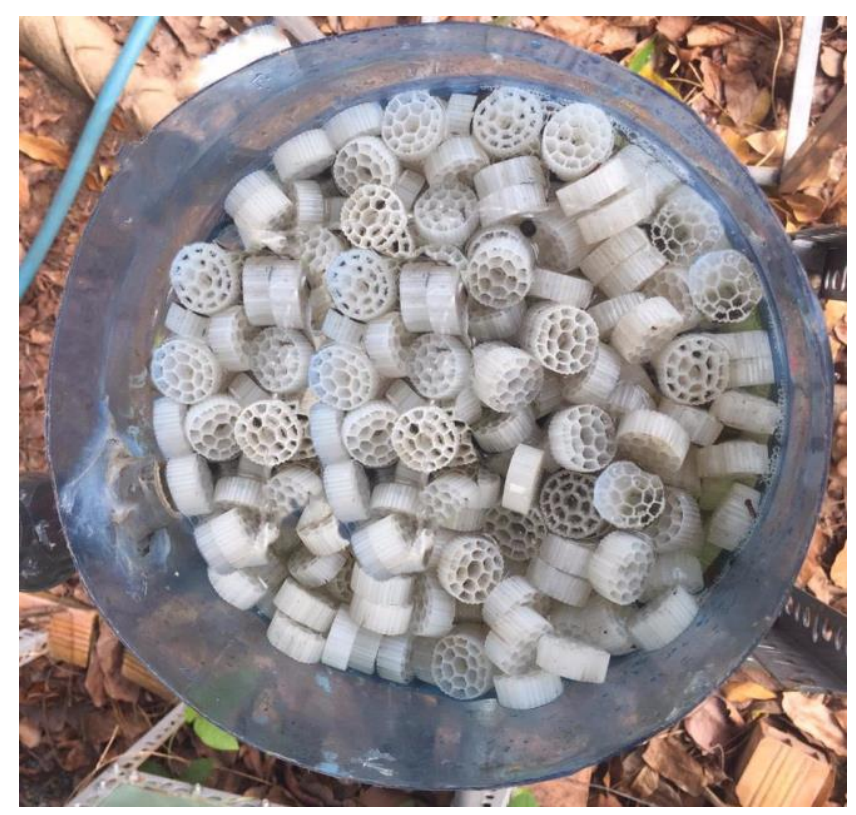

Hình 1. Vật liệu giá thể vi sinh dạng bánh xe

Với bệ lọc thực vật: Thực nghiệm diễn ra với 3 bể lọc thực vật, kí hiệu là bể lọc thực vật $\mathrm{A}$ (wetland $\mathrm{A}$ ), bể lọc thực vật $\mathrm{B}$ (bể đối chứng - wetland $\mathrm{B}$ ) và bể lọc thực vật $\mathrm{C}$ (wetland $\mathrm{C}$ ). Bể $\mathrm{A}$ trồng cây chuối mỏ két, bể $\mathrm{C}$ trồng cây chùm ngây, bể $\mathrm{B}$ trồng chuối mỏ két đối chứng. Nước thải chăn nuôi heo sau Biogas đã qua công đoạn xử lí bằng bể lọc sinh học sẽ vào trong các bể lọc thực vật để xử lý. Trong suốt 2 tuần đầu là giai đoạn để thực vật có thể thích nghi và phát triển với nước thải chăn nuôi để tăng sinh khối, khi thực vật đã bắt đầu ổn định tiến hành khảo sát các thông số kĩ thuật ảnh hưởng đến chất lượng nước đầu ra. Hàng tuần tiến hành đo chiều cao cây để theo dõi sự phát triển cây.

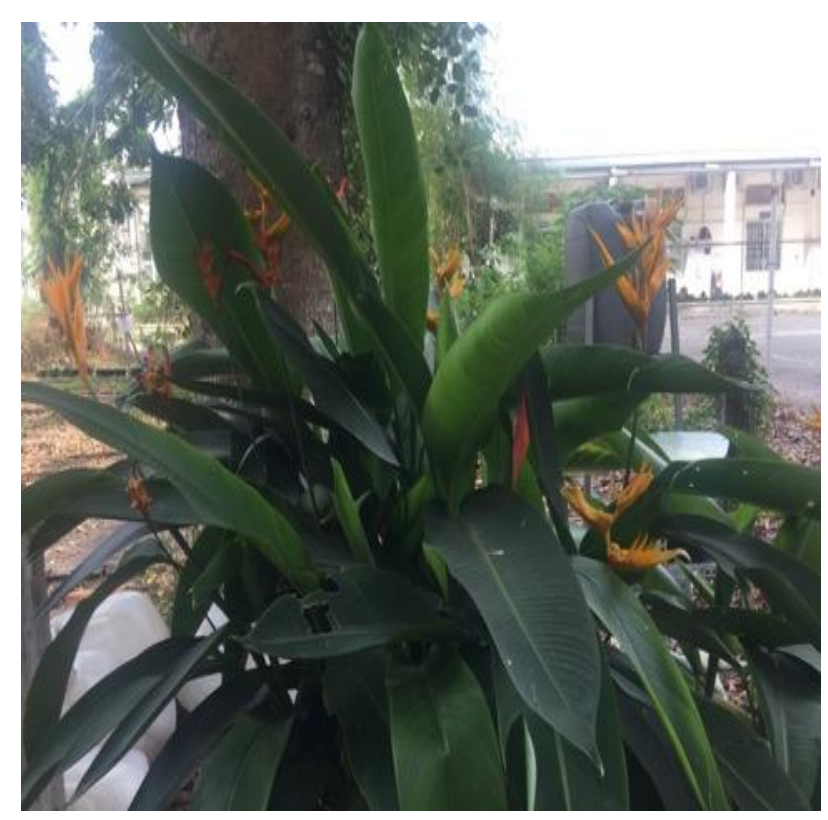

Hình 2. Cây chuối mỏ két

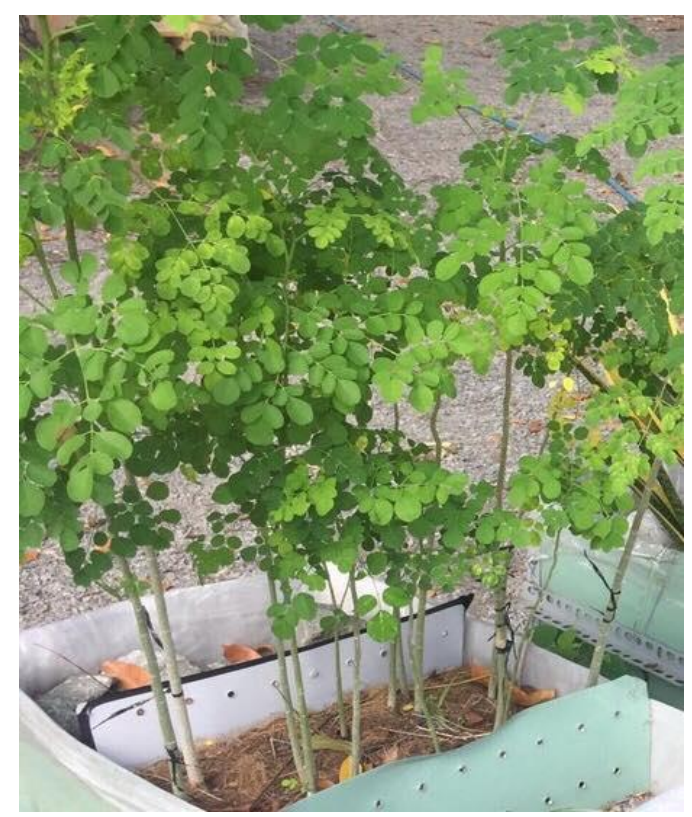

Hình 3. Cây chùm ngây

\subsubsection{Phương pháp phân tích}

Hiệu quả xử lý nước thải được theo dõi thông qua các chỉ tiêu chất lượng nước như $\mathrm{BOD}_{5}, \mathrm{TSS}$, amoni, độ đục (Bảng 2). Các phương pháp đo các chỉ tiêu này tuân thủ theo đúng 
hướng dẫn của nhà sản xuất thiết bị. Các chỉ tiêu này được phân tích tại Phòng thí nghiệm Hóa Môi trường, trường Đại học Mở Thành phố Hồ Chí Minh, cơ sở 3.

\section{Bảng 2}

Thiết bị phân tích sử dụng trong nghiên cứu

\begin{tabular}{|c|c|c|c|}
\hline STT & Chỉ tiêu & Đơn vị & Thiết bị \\
\hline 1 & BOD 5 & $\mathrm{mg} / \mathrm{l}$ & $\begin{array}{r}\text { Dissolved Oxygen Test kit HI3810 } \\
\text { Tủ ủ } 20^{\circ} \mathrm{C}\end{array}$ \\
\hline 2 & TSS & $\mathrm{mg} / \mathrm{l}$ & Giấy lọc thủy tinh, bộ hút chân không, tủ nung và cân phân tích. \\
\hline 3 & Amoni & $\mathrm{mg} / \mathrm{l}$ & Amonia Test kit HI 3824 \\
\hline 4 & Độ đục & $\mathrm{mg} / \mathrm{l}$ & Máy Đo Độ Đục Tiêu Chuẩn ISO HI93703 \\
\hline
\end{tabular}

Nguồn: Kết quả phân tích dữ liệu của nhóm nghiên cứu

Trong nghiên cứu này, sự hiện diện của vi khuẩn nitrat hóa trong đất và trên bề mặt rễ cũng được xác định bằng phương pháp trải trên đĩa petri với môi trường winogradsky.

\subsection{Mô hình nghiên cúu}

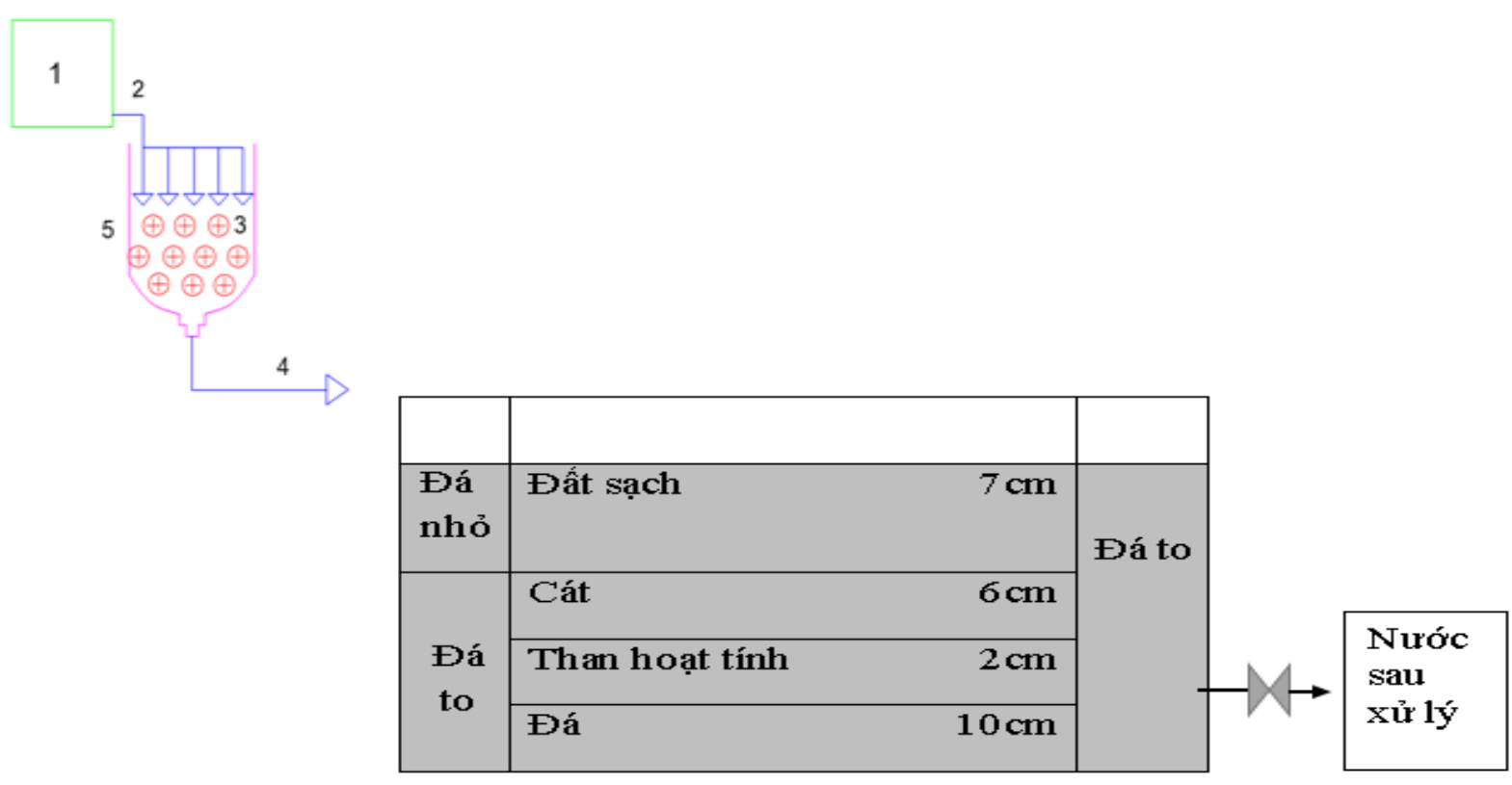

Chú thích: 1. Bể chứa nước thải

2. Dòng thải vào

3. Vật liệu giá thể

4. Dòng thải qua bể lọc 5 . Bể lọc sinh học 


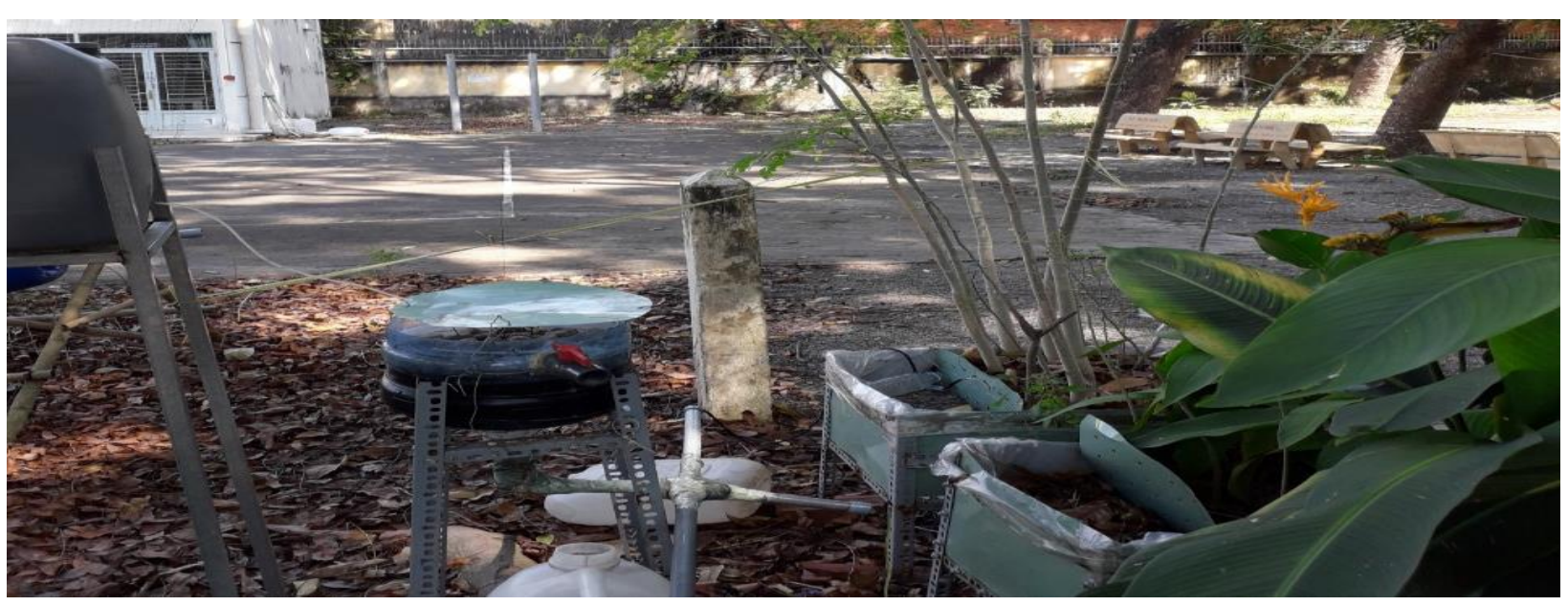

Hình 4. Mô hình nghiên cứu

Cấu tạo của mô hình: Bể phản ứng sinh học giá thể cố định (Biofilter) được làm từ vật liệu là bình nhựa đựng nước $20 \mathrm{~L}$ tái chế cắt bỏ $1 / 3$ phần đầu bình (Hình 1 ), giữ lại phần bình có đường kính $24 \mathrm{~cm}$, chiều cao $20 \mathrm{~cm}$, phần vật liệu chiếm $2 / 3$ bể. Thể tích nước thải có thể chứa trong bể khi đã chứa lớp vật liệu là 5 lít. Bên dưới đáy bể có van xả cặn sau khi bể hoạt động lâu ngày và xuất hiện lượng dưới đáy nhiều. Bình đựng nước đầu vào có thể tích 30 lít có gắn ống dẫn nước, có van điều chỉnh lưu lượng. Ống dẫn được nối với ống nhựa được đục lỗ để nước thải được trải đều xuống mặt vật liệu. Ống dẫn nước thải ở đầu ra bể có van khóa. Bể lọc thực vật được làm từ tôn mỏng và sắt chữ L. Bể có kích thước dài $70 \mathrm{~cm}$, rộng $40 \mathrm{~cm}$, cao $30 \mathrm{~cm}$, chiều cao chân bể $20 \mathrm{~cm}$. Mỗi bể được chia làm 3 ngăn, phân cách bởi 2 tấm tôn đục lỗ. Các lớp vật liệu bao gồm đất sạch, cát, than hoạt tính, đá. Các ống dẫn nước thải đầu vào của bể thực vật chính là các ống dẫn nước thải ở đầu ra của bể lọc sinh học. Ống dẫn nước thải ở đầu ra bể lọc thực vật có van khóa.

Nguyên tắc vận hành mô hình: Mô hình được thiết kế nhằm kết hợp các quá trình xử lý BOD, amoni và loại bỏ TSS, độ đục. Nước thải chăn nuôi sau Biogas được loại bỏ chất rắn lớn, sau đó, được đổ đầy vào bình đựng, mở van chỉnh lưu lượng để nước thải chảy vào bể phản ứng giá thể cố định (biofilter). Nước thải sau khi đi qua bể lọc sinh học (biofilter) sẽ đi vào công đoạn xử lý bể lọc thực vật với thời gian lưu nước khoảng 24 tiếng. Sau một khoảng thời gian chạy hệ thống cần rửa bể vì các cặn đọng lại dưới bể gây ngẽn đầu ra và có thể làm nước thải sau xử lý có hàm lượng TSS cao.

Theo dõi mô hình: Quá trình thí nghiệm chia là hai giai đoạn chính đó là giai đoạn thích nghi và giai đoạn khảo sát các thông số chỉ tiêu nước thải.

Giai đoạn thích nghi: Tại bể lọc sinh học quan sát hạt vật liệu, các vi sinh vật dính bám và thích nghi tạo lớp màng sinh học (biofilm) bao phủ hạt vật liệu. Đối với bể lọc thực vật, theo dõi sự phát triển của cây. Với bể thực vật đối chứng thì nước sạch được sử dụng để so sánh.

Giai đoạn khảo sát các thông số chỉ tiêu chất lượng nước thải: BOD, TSS, amoni, độ đục và đánh giá hiệu suất xử lý và so sánh với QCVN 62-MT:2016/BTNMT đối với bể lọc thực vật.

\section{Kết quả và thảo luận}

\subsection{Giai đoạn thích nghi và hình thành màng biofilm}

Trong thời gian khởi động mô hình, nước sạch được cho chạy qua bể thử nghiệm một tuần. Chủng vi sinh của chế phẩm vi sinh EM PRO-1 được bổ sung với tỷ lệ 1:19 tương ứng 1 lít 
chế phẩm, 19 lít nước. Trong thời gian chạy thử nghiệm 1 tuần với nước trắng, bổ sung $15 \mathrm{ml}$ chế phẩm vi sinh tương đương với $285 \mathrm{ml}$ nước, rải đều trên bề mặt vật liệu, bổ sung nhiều lần. Bề mặt vật liệu chưa có sự thay đổi (Hình 5 ). Sau khoảng thời gian 3 tuần từ lúc chạy nước thải, bắt đầu hình thành màng biofilm (Hình 6), thời gian hình thành màng tương đối nhanh. Màng biofilm mỏng, có thể nhìn bằng mắt thường và nhận biết khi chạm vào. Hiện tượng "tróc màng" cũng xảy ra trong bể biofilter, nước thải đầu ra thường xuyên có những mảng nhờn đục. Nguyên nhân là do các chất hữu cơ trước hết bị hủy bởi vi sinh vật hiếu khí. Tiếp tục thấm sau vào màng, nước thải hết oxi hòa tan và bị phân hủy tiếp tục bởi vi sinh vật kị khí. Khi các chất hữu cơ trong nước thải cạn kiệt, vi sinh vật ở màng sinh học sẽ chuyển sang hô hấp nội bào và khả năng kết dính cũng giảm, dần dần bị cuốn theo dòng nước đầu ra. Vì vậy cần công đoạn xử lý tiếp theo để đảm bảo TSS cho nguồn nước thải đầu ra.

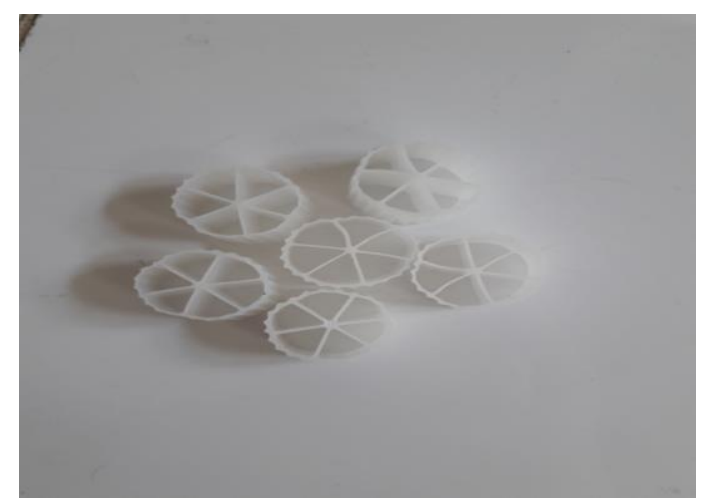

Hình 5(a). Ban đầu

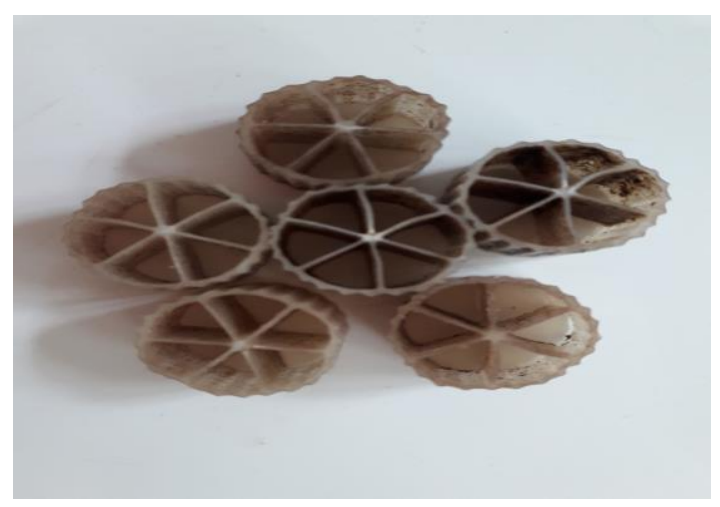

Hình 5(b). Sau thí nghiệm

Hình 5. Bề mặt vật liệu dính bám sau khoảng thời gian xử lý nước thải

Tiến hành dùng khoảng 10 viên vật liệu dính bám lắc nhẹ với $10 \mathrm{ml}$ nước trắng, để chủ động gây hiện tượng tróc màng. Lấy một ít của lớp màng tróc mỏng quan sát dưới kính hiển vi, bước đầu quan sát được vi sinh vật có mặt trong màng biofilm (Hình 6 (a), (b)). Quan sát tương tự cũng được trình bày bởi Costerton, Lewandowski, Caldwell, Korber, và Lappin-Scottb (1995).

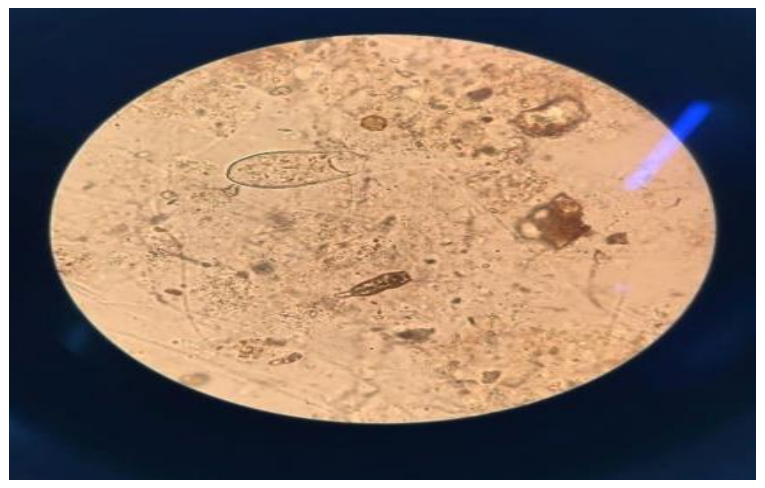

Hình 6(a)

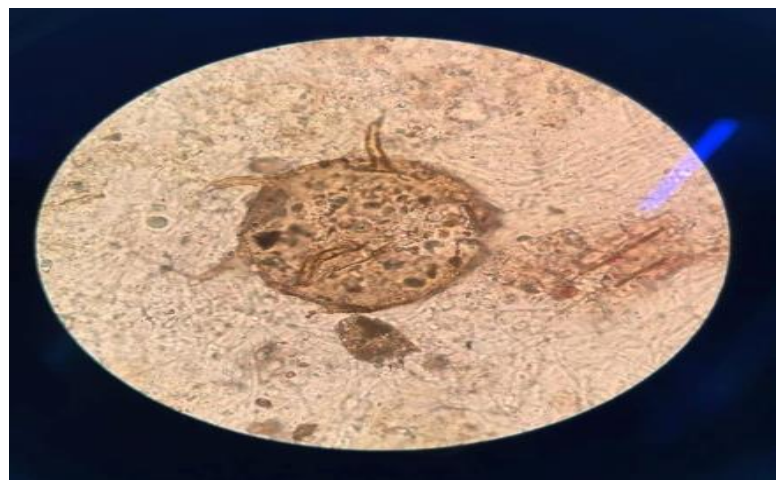

Hình 6(b)

Hình 6. Vi sinh vật quan sát dưới kính hiển vi ở giai đoạn thích nghi

\subsection{Hiệu quả xủ̉ lý BOD, TSS, Amoni, độ đục}

\subsubsection{Hiệu quả xủ lý BOD}

- Bể lọc sinh học 
Sau một tháng chạy ổn định hệ thống, hiệu xuất xử lý ghi nhận tăng dần cho thấy bể biofilter đã bắt đầu xử lý được BOD. Đến tháng 11 và 12 , hiệu xuất cao và ổn định với hiệu suất $28 \%$. Hệ vi sinh vật có trong màng biofilm đã hoạt động tốt và BOD nước thải đã bị vi sinh vật thủy phân dùng làm chất dinh dưỡng giúp làm giảm BOD ở đầu ra nước thải. BOD của nước thải đầu ra bể lọc sinh học vẫn còn rất cao chưa đủ tiêu chuẩn để xả thải ra môi trường. Một phần nguyên do là nồng độ $\mathrm{BOD}$ của nước thải chăn nuôi sau Biogas là khá cao và cũng do mô hình của nghiên cứu nhỏ chưa đủ đáp ứng việc xử lý triệt bể BOD.

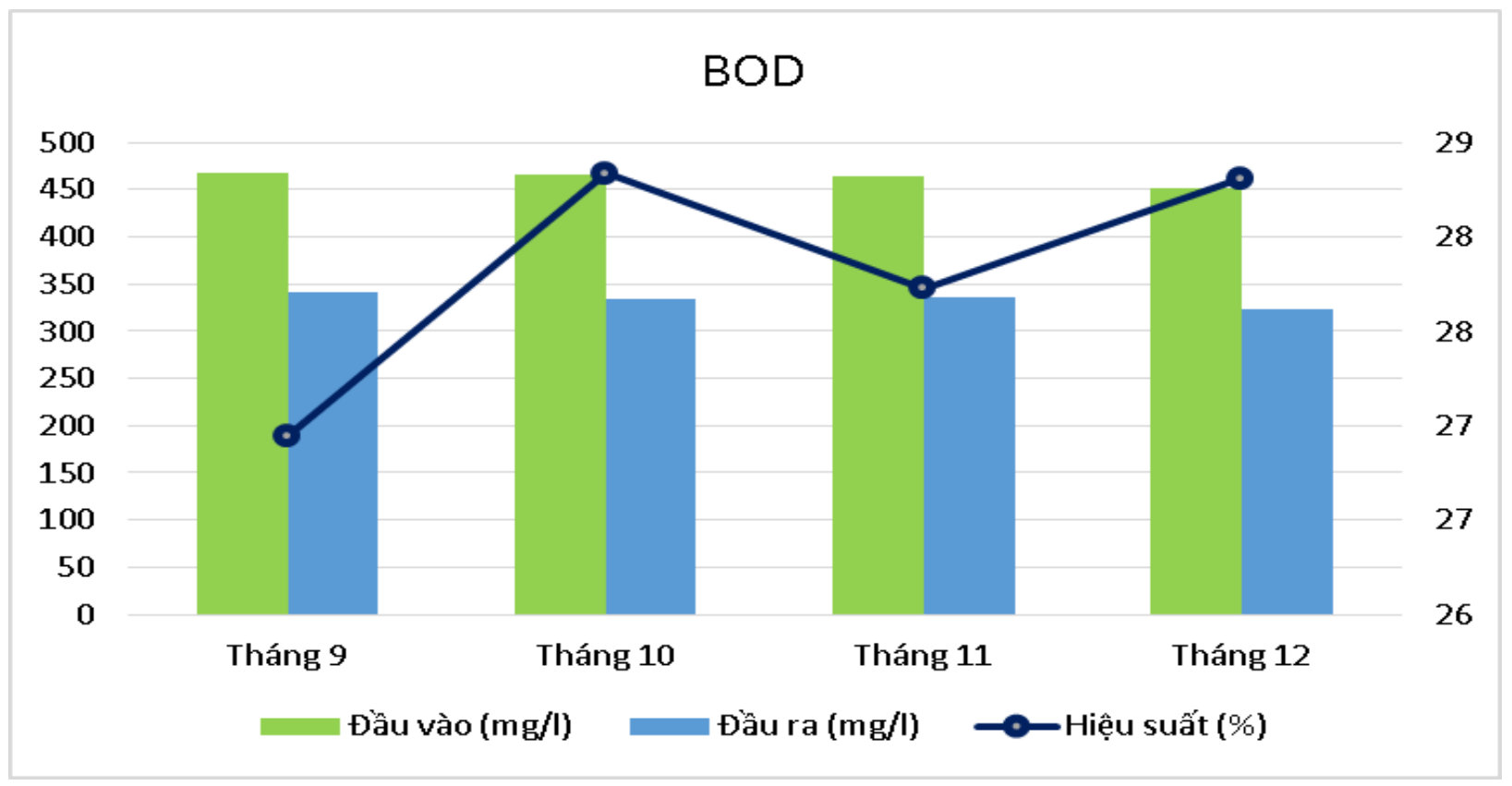

Hình 7. Nồng độ và hiệu xuất BOD trung bình qua 4 tháng nghiên cứu

- Bể lọc thực vật

Theo kết quả tại Hình 8 , nước thải vào bể lọc thực vật có $\mathrm{BOD}$ trung bình dao động từ $320 \mathrm{mg} / \mathrm{l}$ đến $340 \mathrm{mg} / \mathrm{l}$ vượt ngưỡng xả thải ra môi trường rất cao so với QCVN 62MT:2016/BTNMT là $100 \mathrm{mg} / 1$. Nước thải sau khi đi qua 2 bể lọc thực vật, BOD đã được xử lý giảm xuống còn $220 \mathrm{mg} / \mathrm{l}$ đến $260 \mathrm{mg} / \mathrm{l}$. Tại bể lọc thực vật A, giá trị BOD sau xử lý dao động trung bình tại $220 \mathrm{mg} / \mathrm{l}$. Tại bể lọc thực vật $\mathrm{C}$, giá trị BOD thấp nhất là $230 \mathrm{mg} / \mathrm{l}$ và cao nhất là $260 \mathrm{mg} / \mathrm{l}$. Dù BOD đầu ra giảm xuống so với đầu vào nhưng vẫn chưa đạt tiêu chuẩn xả thải. Khi so sánh khả năng xử lý BOD của 2 loài thực vật tại hai bể lọc thì nhận thấy không có sự chênh lệch nhiều. Do điều kiện xét nghiệm BOD trong phòng thí nghiệm và đặc tính BOD của nước thải ở cơ sở chăn nuôi cao nên có những sai số. 


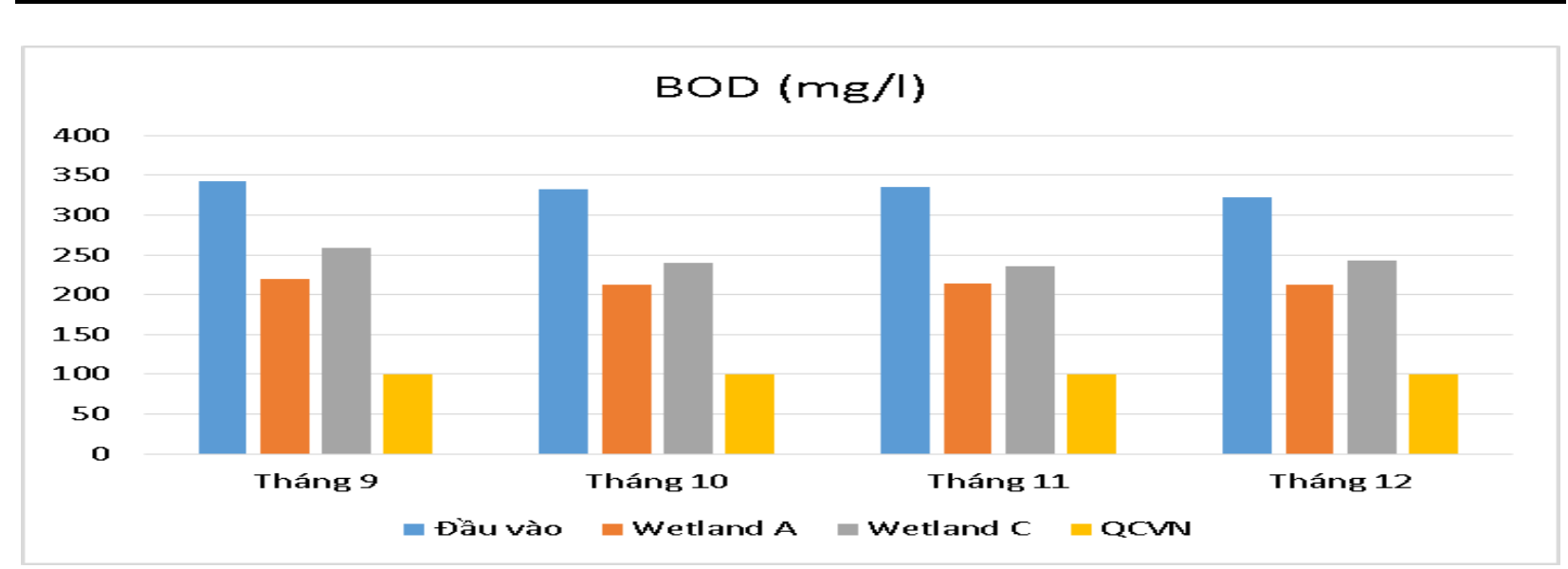

Hình 8. Nồng độ BOD trung bình qua 4 tháng nghiên cứu

Theo kết quả nghiên cứu, hiệu quả xử lý BOD trung bình của 2 bể lọc thực vật từ $24 \%$ $36 \%$. Tại bể lọc thực vật $\mathrm{A}$ và bể lọc thực vật $\mathrm{C}$, ta nhận thấy không có sự chênh lệch lớn giữa các 2 thực vật chuối mỏ két và chùm ngây, hiệu suất xử lý tại bể lọc thực vật $\mathrm{A}$ cao hơn bể lọc thực vật $\mathrm{C}$. Trong đó, hiệu suất xử lý trung bình thấp nhất là $24 \%$ ứng với chùm ngây tại bể lọc thực vật $\mathrm{C}$, cao nhất là $36 \%$ ứng với chuối mỏ két tại bể lọc thực vật $\mathrm{A}$. Kết quả cho thấy mặc dù hiệu quả xử lí BOD của cây chuối mỏ két chưa cao, nhưng thể hiện được khả năng xử lý cao và ổn định hơn so với cây chùm ngây. Trong nghiên cứu của Thai và Le (2016), tác giả đã thu nhận được hiệu quả xử lý rất cao đối với cây sậy, nến, cỏ vetiver đều trên $90 \%$, nước thải đầu ra đạt tiêu chuẩn xả thải. Sự khác biệt giữa nghiên cứu này và nghiên cứu của nhóm tác giả trên có thể lý giải bởi nồng độ $\mathrm{BOD}$ đầu vào trong nghiên cứu này rất cao (> $300 \mathrm{mg} / \mathrm{L})$.

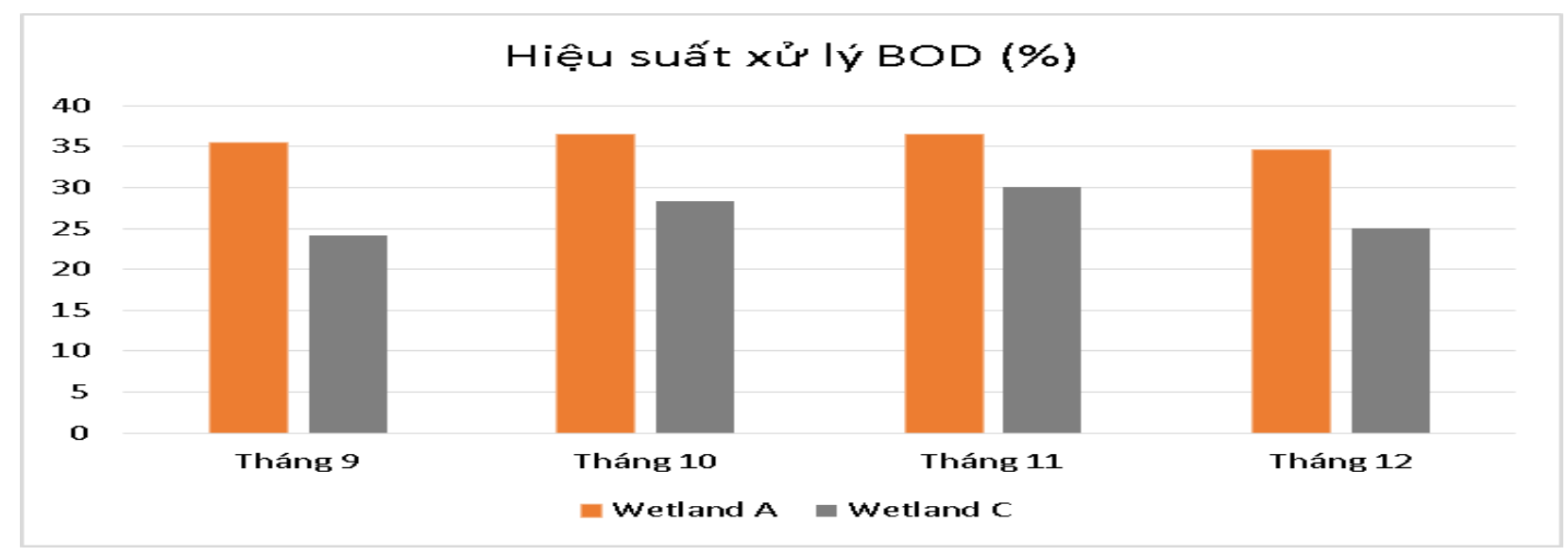

Hình 9. Hiệu suất xử lý BOD trung bình qua 4 tháng nghiên cứu

Kết quả từ nghiên cứu này bước đầu cho thấy, nước thải chăn nuôi heo sau Biogas khi được xử lý bằng bể lọc sinh học kết hợp bãi lọc thực vật thì nồng độ BOD giảm đáng kể. Từ nước thải đầu vào có nồng độ BOD khá cao $452 \mathrm{mg} / \mathrm{l}$, sau khi qua bể lọc sinh học đã giảm xuống dao động từ $320 \mathrm{mg} / \mathrm{l}$ đến $340 \mathrm{mg} / \mathrm{l}$ và qua bể lọc thực vật còn $220 \mathrm{mg} / \mathrm{l}$ đến $260 \mathrm{mg} / \mathrm{l}$ đối với cả 2 loại cây.

\subsubsection{Hiệu quả xủ lý TSS}

- Bể lọc sinh học

Hiệu xuất xử lý TSS từ $30 \%$ giảm xuống còn $25 \%$ từ tháng 9 đến tháng 10 , sau đó tăng dần và đạt $35 \%$ trong tháng 12 (Hình 10 ). Hiệu quả xử lý tổng rắn lơ lửng có thể giải thích bởi bề 
mặt các vật liệu lớn, có các góc cạnh nhỏ góp phần giữ lại TSS. Bên cạnh đó, vi sinh trong bể phân hủy rắn hữu cơ, một thành phần của TSS, làm giảm TSS đầu ra. Sau 1 đến 2 tháng hoạt động bể, bể được xả cặn một lần để đảm bảo không làm nghẽn đầu ra và giữ TSS được ổn định, do bể được thiết kế đơn giản nên quá trình rửa bể sẽ tiến hành thủ công. Mặc dù hiệu quả xử lý TSS là cao, tuy nhiên TSS dòng ra vẫn cao chưa đủ để xả thải, vì một phần màng biofilm xảy ra hiện tượng bong tróc, đây là quá trình sinh hóa tự nhiên của màng sinh học. Qua nghiên cứu này, kết quả cho thấy để xử lý nước thải chăn nuôi heo sau Biogas một cách hiệu quả thì lọc sinh học chỉ nên là công trình tiền xử lý nhằm làm giảm TSS và BOD. Chính vì nước thải chăn nuôi heo sau Biogas đã qua bể lọc sinh học TSS vẫn cao nên tiếp tục được xử lý bằng bể lọc thực vật xử lý đạt QCVN. Uu điểm của bể Biolfilter có thể thấy là làm giảm tải lượng ô nhiễm cho các công đoạn xử lý tiếp theo.

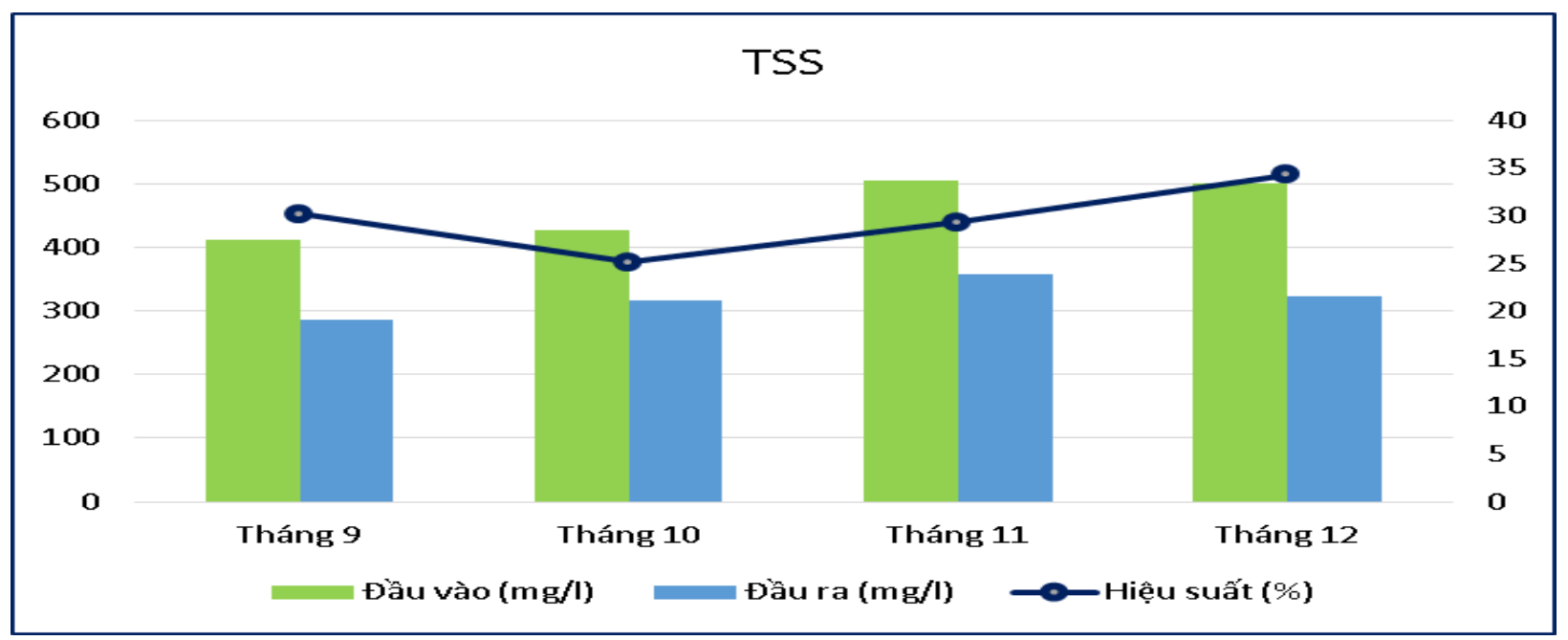

Hình 10. Nồng độ và hiệu xuất TSS trung bình qua 3 tháng nghiên cứu

- Bể lọc thực vật

Ta thấy giá trị đầu vào nước thải có TSS trung bình dao động từ $280 \mathrm{mg} / \mathrm{l}$ đến $350 \mathrm{mg} / \mathrm{l}$ vượt ngưỡng xả thải ra môi trường rất cao so với QCVN 62-MT:2016/BTNMT là 150 mg/l. Nước thải sau khi đi qua bể lọc thực vật, TSS đã được xử lý giảm xuống còn $145 \mathrm{mg} / \mathrm{l}$ đến 220 $\mathrm{mg} / \mathrm{l}$. Tại bể lọc thực vật $\mathrm{A}$ (wetland A) giá trị TSS trung bình dao động từ $1450 \mathrm{mg} / \mathrm{l}$ đến 190 $\mathrm{mg} / \mathrm{l}$, còn bể lọc thực vật $\mathrm{C}$ (wetland $\mathrm{C}$ ) giá trị TSS trung bình dao động thấp nhất là $180 \mathrm{mg} / \mathrm{l}$ và cao nhất là $220 \mathrm{mg} / \mathrm{l}$. Các tháng $9,10,12$ TSS đầu ra giảm xuống so với đầu vào nhưng vẫn chưa đủ tiêu chuẩn xả thải, riêng tháng 11 TSS đã giảm xuống $145 \mathrm{mg} / 1$ và đủ tiêu chuẩn xả thải đối với bể lọc thực vật $\mathrm{A}$ ứng với cây chuối mỏ két, cho thấy mô hình thí nghiệm đã xử lý rất tốt TSS. Về khả năng xử lý TSS của 2 loài thực vật không chênh lệch nhau nhiều nhưng cây chuối mỏ két có tiềm năng xử lý hàm lượng TSS trong nước thải chăn nuôi heo sau Biogas hơn cây chùm ngây. Do điều kiện xét nghiệm TSS trong phòng thí nghiệm và đặc tính TSS của nước thải ở cơ sở chăn nuôi cao nên TSS của nước thải sau xử lý so với QCVN thì vẫn chưa đạt để thải ra môi trường nhưng đây là tiềm năng để ứng dụng công nghệ bãi lọc thực vật. 


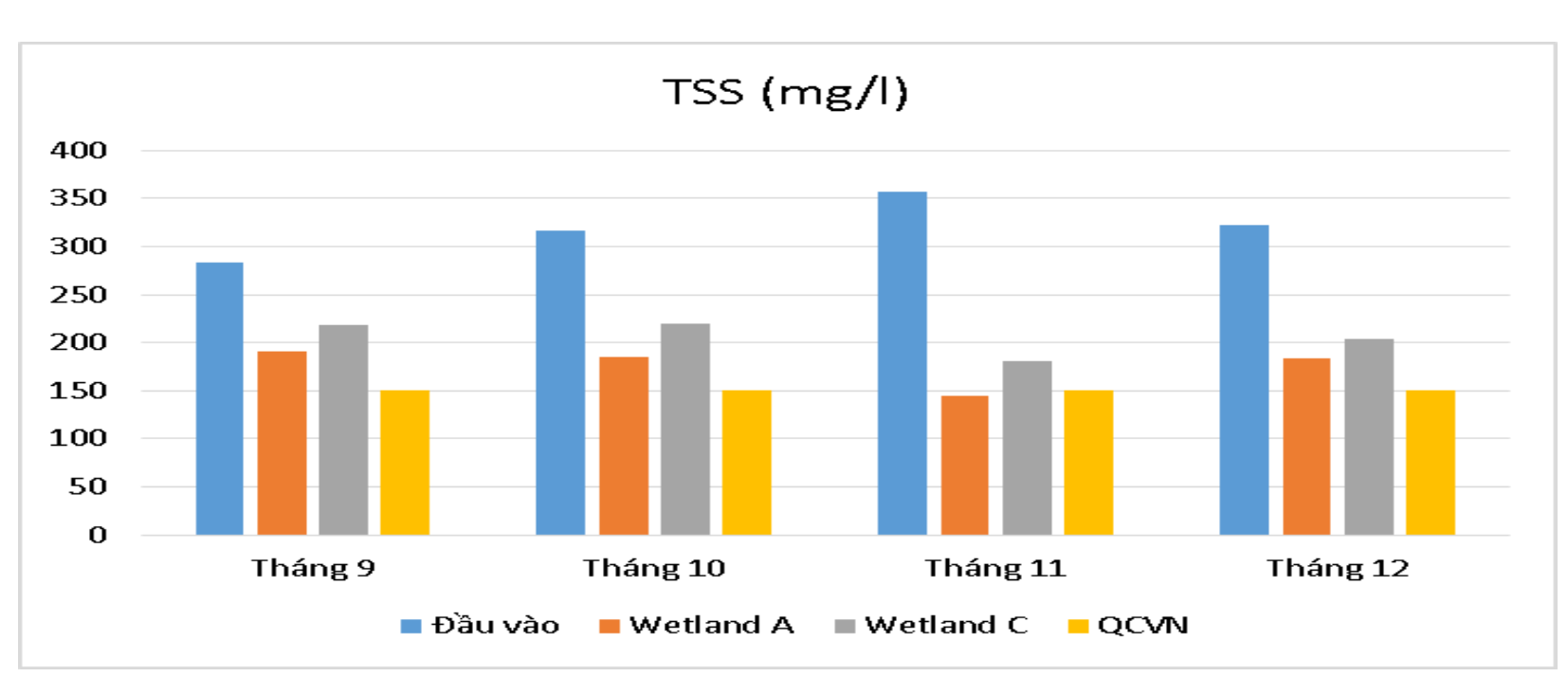

Hình 11. Nồng độ TSS trung bình qua 4 tháng nghiên cứu

Hiệu suất xử lý TSS của 2 bể lọc thực vật $\mathrm{A}$ và bể lọc thực vật $\mathrm{C}$ có dao động khá lớn từ $25 \%-59 \%$. Hiệu suất xử lý TSS tại Bãi lọc thực vật $\mathrm{A}$ cao hơn wetand $\mathrm{C}$. Trong đó, hiệu suất xử lý trung bình thấp nhất là $25 \%$ ứng với chùm ngây tại bể lọc thực vật $\mathrm{C}$, cao nhất là $59 \%$ ứng với chuối mỏ két tại bể lọc thực vật $\mathrm{A}$. Do thiết kế, sử dụng vật liệu đất, than hoạt tính và xác chết vi sinh vật trong bể có thể dẫn tới sự chênh lệnh hiệu suất xử lý của bể. Trong nghiên cứu Thai và Le (2016), hiệu quả xử lý TSS thu nhận được luôn cao hơn 90\% trong thí nghiệm với cây sậy, nến, vetiver. Nhóm tác giả trên cũng thu nhận được nước thải đầu ra luôn đạt chuẩn xả thải, sự khác biệt so với nghiên cứu này có thể lý giải một phần vì nước thải sinh hoạt của nhóm tác giả Anh và Chi có nồng độ TSS đầu vào tương đối thấp $(100-150 \mathrm{mg} / \mathrm{L})$ hơn so với nghiên cứu này (TSS > $290 \mathrm{mg} / \mathrm{L}$ ). Ngoài ra yếu tố kỹ thuật mô hình cũng ảnh hưởng rất lớn đến hiệu quả xử lý TSS trong nghiên cứu này.

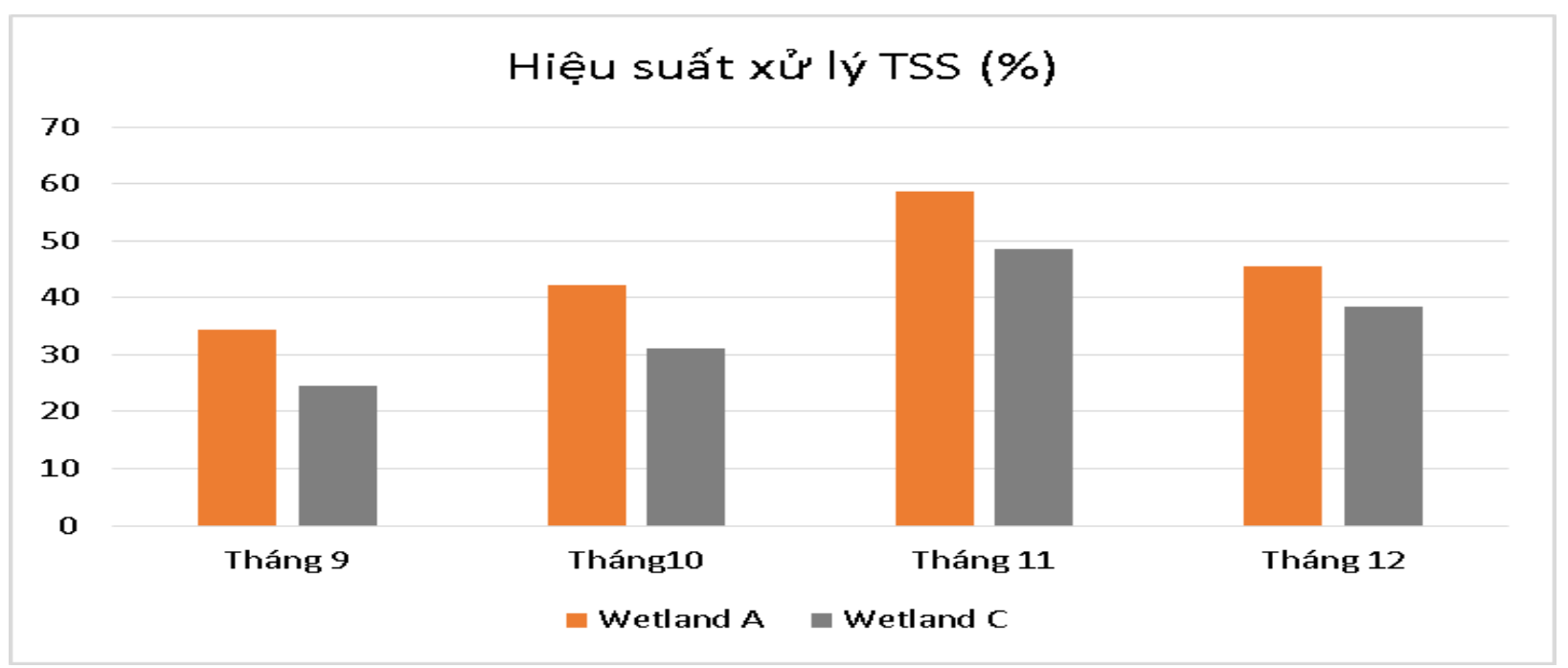

Hình 12. Hiệu xuất xử lý TSS trung bình qua 4 tháng nghiên cứu

Nhìn chung nước thải chăn nuôi heo sau Biogas khi được xử lý bằng bể lọc sinh học kết hợp bãi lọc thực vật thì nồng độ TSS giảm đáng kể. Từ nước thải đầu vào có nồng độ TSS khá cao từ 400 - $500 \mathrm{mg} / \mathrm{l}$, sau khi qua bể lọc sinh học đã giảm xuống dao động từ $290 \mathrm{mg} / \mathrm{l}$ đến 350 $\mathrm{mg} / \mathrm{l}$ và qua bể lọc thực vật còn $145 \mathrm{mg} / \mathrm{l}$ đến $220 \mathrm{mg} / \mathrm{l}$ đối với cả 2 loại cây. 


\subsubsection{Hiệu quả xủi lý Amoni}

- Bể lọc sinh học

Bể phản ứng phản ứng sinh học giá thể cố định tạo môi trường hiếu khí để vi khuẩn Nitrosomonas và vi khuẩn Nitrobacter hoạt động tốt đồng thời xử lý Amoni. Mặc dù hiệu suất xử tăng dần và đạt mức cao $29 \%$ vào tháng 11 . Tuy nhiên việc xử lý amoni phụ thuộc vào quá trình hình thành cũng như hiện tượng tróc màng của màng sinh học. Điều này làm việc thông số amoni trong nước thải đầu ra không ổn định. Việc này càng góp phần làm rõ nhận định bể phản ứng giá thể cố định là giai đoạn tiền xử lý cần có công đoạn xử lý tiếp theo để đảm bảo việc xả thải đúng qui định. Trong nghiên cứu đánh giá khả năng xử lý nước thải giết mổ của bể lọc sinh học, Mai, Trang, Pham, và Tran (2019) ghi nhận được hiệu quả lên đến 66\%. Sự khác biệt với nghiên cứu này có thể do nồng độ amoni đầu vào của nghiên cứu này khá cao, $\left[\mathrm{NH}_{4}{ }^{+}\right]$luôn lớn hơn $300 \mathrm{mg} / \mathrm{L}$.

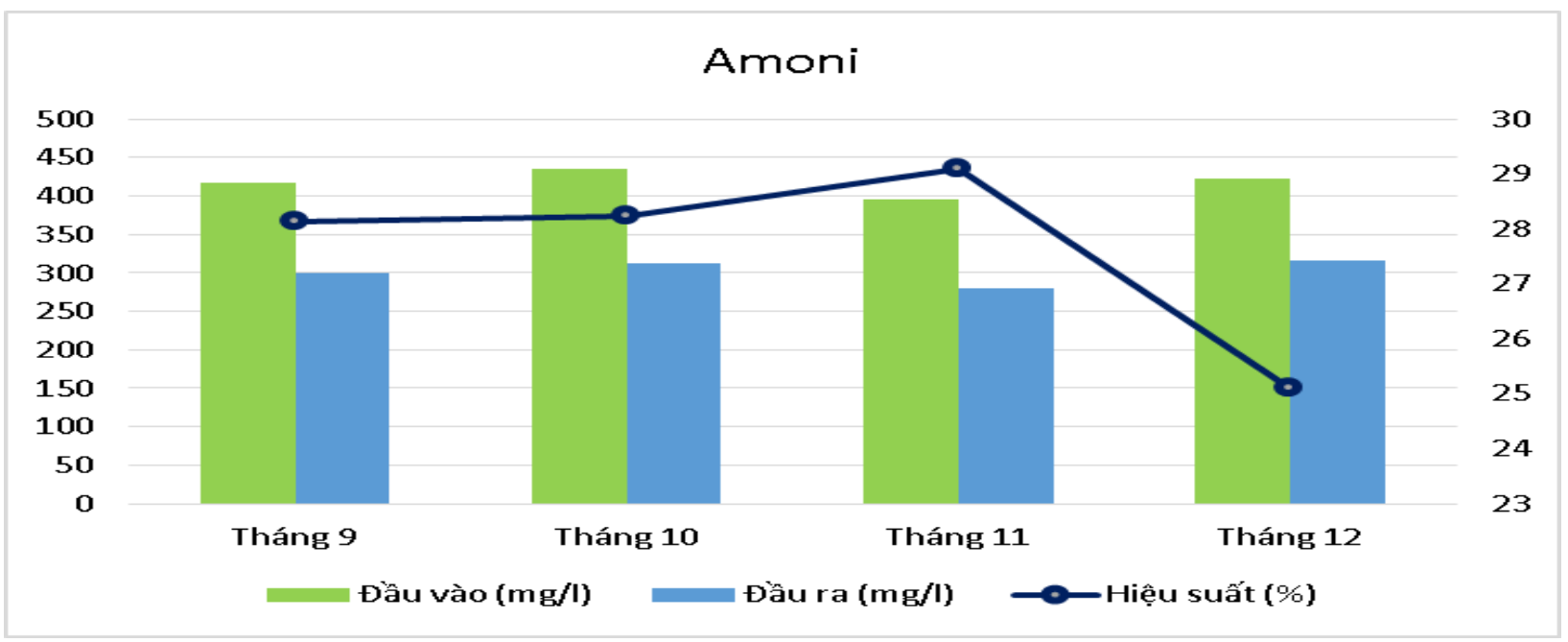

Hình 13. Nồng độ và hiệu suất xử lý amoni trung bình qua 4 tháng nghiên cứu

- Bể lọc thực vật

Chỉ số đối chứng trên đồ thị Hình 14 thể hiện sự đối chứng với QCNV 62MT:2016/BTNMT tổng Nito là $150 \mathrm{mg} / \mathrm{l}$. Nhưng giả sử trong nước thải không có Nitrat và Nitrit thì Amoni được so sánh với đối chứng. Đối chứng được tính như sau:

$$
\text { Đối chứng }=\left(\text { Nito tổng } \times \mathrm{M}_{\mathrm{NH} 4}{ }^{+}\right) / \mathrm{M}_{\mathrm{N}}=(150 \times 20) / 16=187,5 \mathrm{mg} / \mathrm{l}
$$

Giá trị đầu vào nước thải có Amoni từ $280 \mathrm{mg} / 1$ đến $320 \mathrm{mg} / 1$ vượt ngưỡng xả thải ra môi trường (so với đối chứng là 187,5 mg/l). Nước thải sau khi đi qua 2 bể lọc thực vật, Amoni đã được xử lý giảm xuống còn $160 \mathrm{mg} / \mathrm{l}$ đến $230 \mathrm{mg} / \mathrm{l}$. Tại đầu ra của bể lọc thực vật $\mathrm{A}$ giá trị amoni thấp nhất là $160 \mathrm{mg} / \mathrm{l}$, cao nhất là $200 \mathrm{mg} / \mathrm{l}$. Còn tại đầu ra bể lọc thực vật $\mathrm{C}$ giá trị amoni thấp nhất là $190 \mathrm{mg} / \mathrm{l}$ và cao nhất là $230 \mathrm{mg} / \mathrm{l}$. Các tháng 9,10,12 amoni đầu ra giảm xuống so với đầu vào nhưng vẫn chưa đủ tiêu chuẩn xả thải nhưng không chênh lệch lớn so với đối chứng, riêng tháng 11 amoni đã giảm xuống $160 \mathrm{mg} / 1$ và đủ tiêu chuẩn xả thải đối với bể lọc thực vật $\mathrm{A}$ ứng với cây chuối mỏ két, cho thấy mô hình thí nghiệm đã chuyển hóa rất tốt amoni.

Theo Park và Yoo (2009) thì thực vật trong bãi lọc cung cấp môi trường thích hợp cho vi sinh vật vùng rễ thực hiện quá trình phân huỷ sinh học (hiếu khí) bằng cách vận chuyển oxi vào vùng rễ̂. Amoni được loại bỏ trong các bãi lọc thực vật nhờ cơ chế chủ yếu: Nitrat hóa/khử nitrat, sự bay hơi của amoniac $\left(\mathrm{NH}_{3}\right)$, sự hấp thụ của thực vật. Ngoài ra một lượng lớn các chất hữu cơ 
cũng được tạo ra từ rễ của thực vật. Đây là một nguồn Cacbon hữu cơ cung cấp cho quá trình khử nitrat và do đó làm tăng sự loại bỏ $\mathrm{NO}_{3}{ }^{-}$trong nước thải. Đối với lớp bề mặt chung giữa đất và rễ, oxi từ khí quyển khuyếch tán vào vùng rễ qua lá, thân, gốc, rễ của các cây trồng trong bãi lọc và tạo nên một lớp giàu oxi tương tự như lớp bề mặt chung giữa đất và nước. Quá trình Nitrat hoá diễn ra ở vùng rễ hiếu khí, tại đây $\mathrm{NH}_{4}{ }^{+}$bị oxy hoá thành $\mathrm{NO}_{3}{ }^{-}$. Phần $\mathrm{NO}_{3}{ }^{-}$không bị cây trồng hấp thụ sẽ khuyếch tán vào vùng thiếu khí và bị khử thành $\mathrm{N}_{2}$ và $\mathrm{N}_{2} \mathrm{O}$ do quá trình khử Nitrat. Vì điều kiện thí nghiệm nên việc đi sâu theo dõi sự chuyển hóa khử nitrat trong đất và vùng rễ là chưa thực hiện được trong nghiên cứu này.

Sự hiện diện của 2 loài vi khuẩn nitrat hóa tiêu biểu là Nitrosomonas và Nitrobacter có trong đất, rễ cây được xác định bằng phương pháp trải petri trên môi trường winogradsky. Mẫu đất và rễ cây tại bể lọc thực vật $\mathrm{A}$ và $\mathrm{C}$ được mang đi phân lập và xác định sự hiện diện của vi khuẩn nitrat hóa. Hai môi trường nuôi cất được sử dụng để xác định hai nhóm vi khuẩn: nhóm oxi hóa ammonia thành nitrite (môi trường winogradsky 1) và nhóm vi khuẩn oxi hóa nitrite thành nitrate (môi trường winogradsky 2). Mỗi mẫu sẽ được dập mẫu và trải đĩa 3 nồng độ thường từ $10^{5}-10^{7}$, mỗi nồng độ lập lại 2 lần. Kết quả cho thấy, tại bể lọc thực vật $\mathrm{A}$, mẫu đất có sự hiện diện vi khuẩn Nitrosomonas là $8 \times 10^{7} \mathrm{CFU} / \mathrm{g}$, vi khuẩn Nitrobacter là $2,2 \times 10^{7} \mathrm{CFU} / \mathrm{g}$ và đối với mẫu rễ hàm lượng hiện diện vi khuẩn Nitrosomonas là $1,01 \times 10^{9} \mathrm{CFU} / \mathrm{g}$, vi khuẩn Nitrobacter là 1,66 x $10^{9} \mathrm{CFU} / \mathrm{g}$. Tại bể lọc thực vật $\mathrm{C}$, ở mẫu đất vi khuẩn Nitrosomonas là 7,5 x $10^{7} \mathrm{CFU} / \mathrm{g}$, vi khuẩn Nitrobacter là 4,55 x $10^{7} \mathrm{CFU} / \mathrm{g}$ và đối với mẫu rễ vi khuẩn Nitrosomonas là 6,55 x $10^{8} \mathrm{CFU} / \mathrm{g}$, vi khuẩn Nitrobacter là 1,15 x $10^{7} \mathrm{CFU} / \mathrm{g}$.

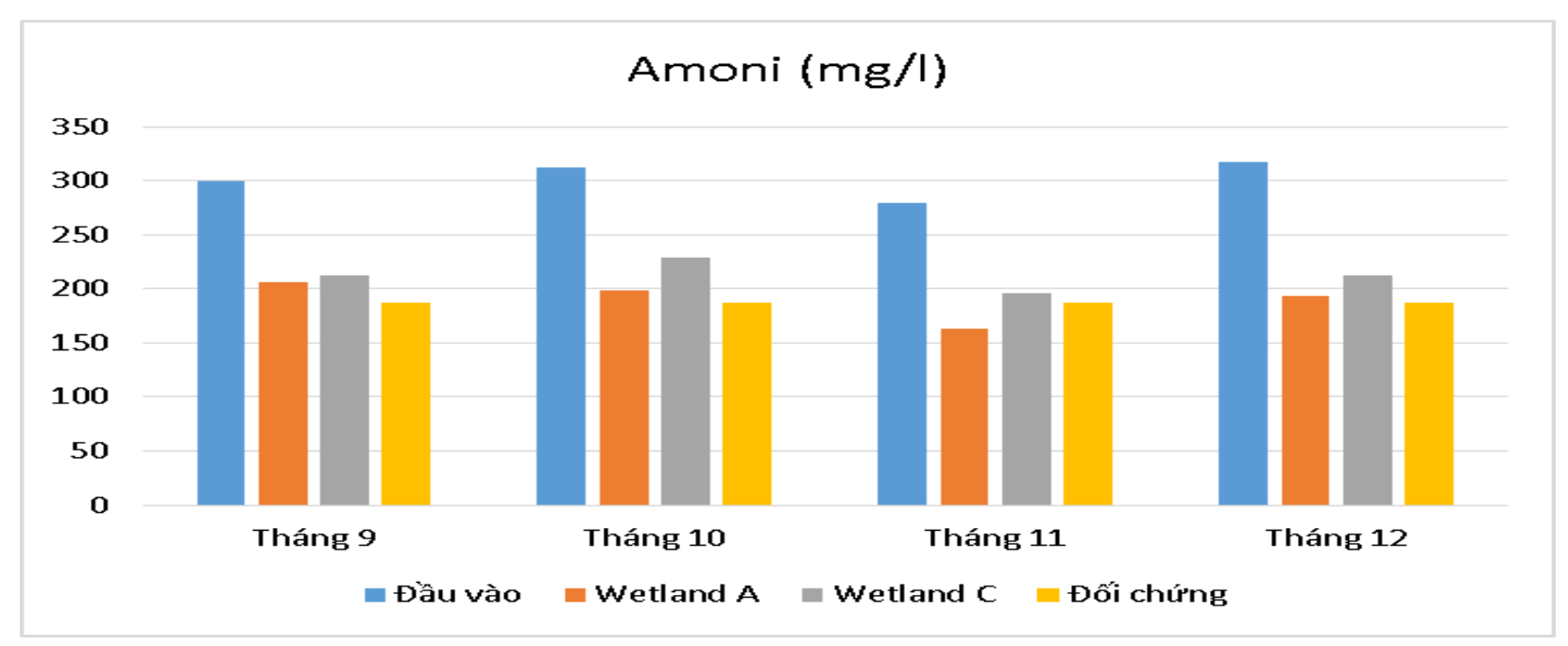

Hình 14. Nồng độ Amoni trung bình qua 4 tháng nghiên cứu

Hiệu suất xử lý Amoni của 2 bể lọc thực vật từ $23 \%$ - $41 \%$. Hiệu suất xử lý amoni tại bể lọc thực vật $\mathrm{A}$ cao hơn wetand $\mathrm{C}$. Trong đó, hiệu suất xử lý thấp nhất là $23 \%$ ứng với chùm ngây tại bể lọc thực vật $\mathrm{C}$, cao nhất là $41 \%$ ứng với chuối mỏ két tại bể lọc thực vật $\mathrm{A}$. Mô hình trồng chuối mỏ két đã thể hiện được khả năng xử lý vượt trội hơn hẳn loài thực vật còn lại, điều này một lần nữa giúp khẳng định chuối mỏ két là loài thực vật rất có tiềm năng cho việc cung cấp oxy vào bên trong mô hình nghiên cứu để xử lí Amoni. Trong nghiên cứu của nhóm tác giả Thai và Le (2016), hiệu quả xử lý amoni cao nhất thu nhận được lên đến 55\% đối với thực vật nghiên cứu là cây sậy, hiệu suất cao hơn so với hiệu suất $41 \%$ thu nhận được trong nghiên cứu này với chuối mỏ két. Tuy nhiên nhóm tác giả Thai và Le (2016) vẫn chưa kiểm tra sự hiện diện vi khuẩn nitrat hóa và khử nitrat có trong đất cũng như rễ cây nên rất khó đánh giá hiệu quả cao trong việc chuyển hóa amoni có phần đóng góp của nhóm vi khuẩn hay không. 


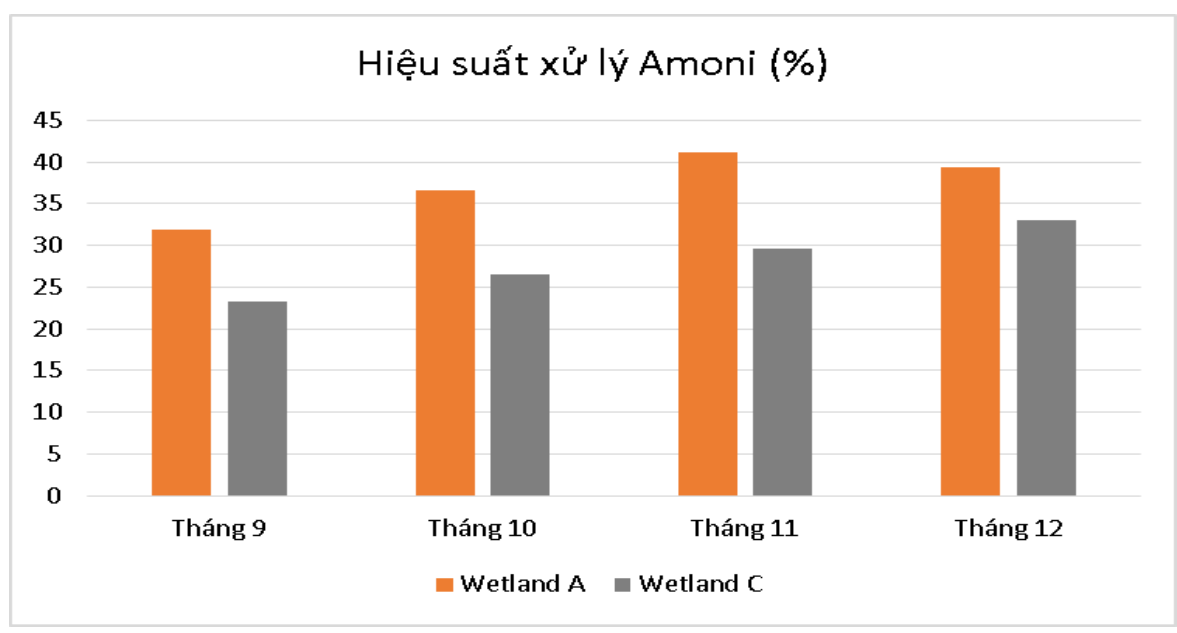

Hình 15. Hiệu suất xử lý Amoni trung bình qua 4 tháng nghiên cứu

Từ kết quả từ nghiên cứu này cho thấy nước thải chăn nuôi heo sau Biogas khi được xử lý bằng bể lọc sinh học kết hợp bãi lọc thực vật thì nồng độ amoni giảm đáng kể. Từ nước thải đầu vào có nồng độ amoni khá cao $390 \mathrm{mg} / \mathrm{l}$ đến 440mg/l, sau khi qua bể lọc sinh học đã giảm xuống dao động từ $255 \mathrm{mg} / \mathrm{l}$ đến $310 \mathrm{mg} / \mathrm{l}$ và qua bể lọc thực vật còn $160 \mathrm{mg} / \mathrm{l}$ đến $230 \mathrm{mg} / \mathrm{l}$ đối với cả 2 loại thực vật.

\subsubsection{Hiệu quả xủ lý độ đục}

- Bể lọc sinh học

Bể lọc sinh học giải quyết khá tốt độ đục, biểu hiện ở việc hiệu suất xử lý trung bình dao động khoảng $24 \%-26 \%$. Việc lọc sinh học giải xử lý tốt chất lắng lơ lửng cũng chính là giảm độ đục trong nước thải nước thải chăn nuôi heo sau Biogas. Nước thải chăn nuôi heo sau Biogas đã qua bể lọc sinh học có giá trị độ đục còn cao, gây ảnh hưởng đến màu sắc của nước khi xả thải ra môi trường nếu không qua hệ thống lọc thực vật.

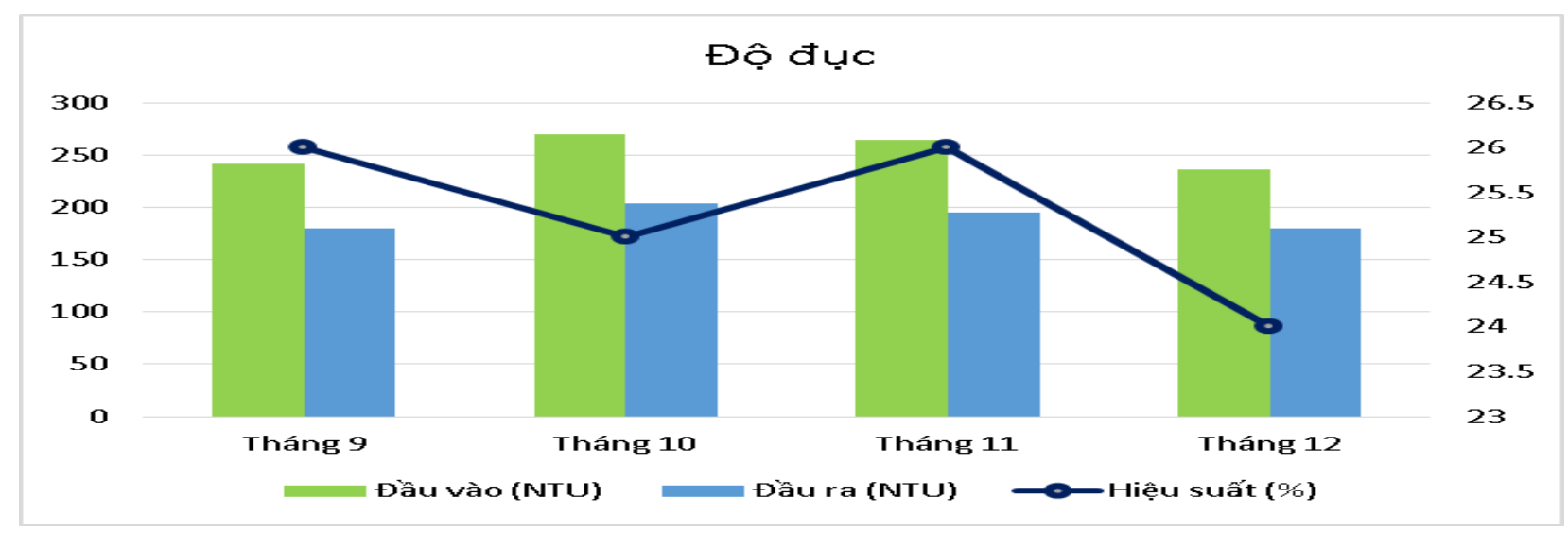

Hình 16. Nồng độ và hiệu xuất độ đục trung bình qua 4 tháng nghiên cứu

- Bể lọc thực vật

Ta thấy giá trị đầu vào nước thải có độ đục trung bình dao động từ 155 NTU đến 200 NTU. Sau khi qua xử lý tại 2 bể lọc thực vật thì độ đục giảm đáng kể. Độ đục trung bình sau xử lý tại bể lọc thực vật $\mathrm{A}$ (Bãi lọc thực vật $\mathrm{A}$ ) dao động từ $110 \mathrm{NTU}$ đến 130 NTU và tại bể lọc thực vật $\mathrm{C}$ độ đục giảm xuống còn 120 NTU đến 140 NTU. 


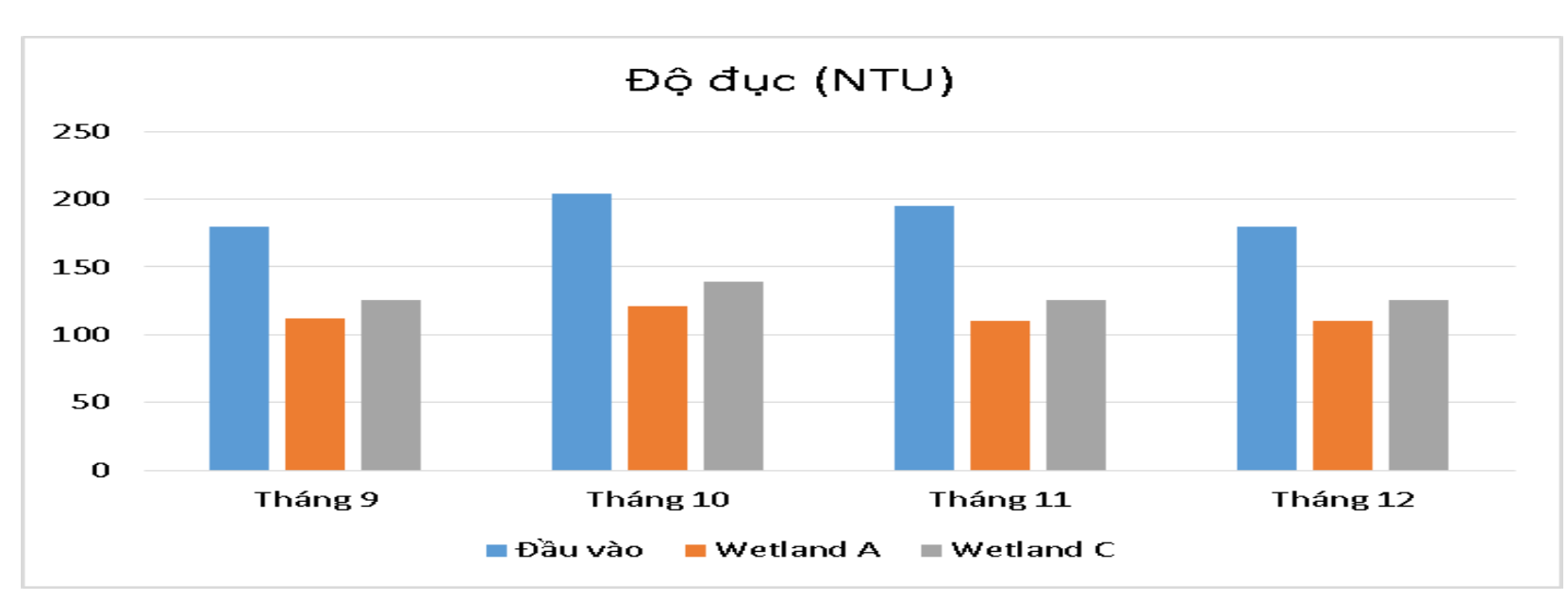

Hình 17. Nồng độ độ đục trung bình qua 4 tháng nghiên cứu

Hiệu quả xử lý ở 2 bể lọc thực vật và thực vật khác nhau đều cao từ $30 \%-41 \%$. Tại bể lọc thực vật $\mathrm{A}$ (wetland $\mathrm{A}$ ) và bể lọc thực vật $\mathrm{C}$ (wetland $\mathrm{C}$ ), ta nhận thấy không có sự chênh lệch lớn giữa các 2 thực vật chuối mỏ két và chùm ngây, nhưng hiệu suất xử lý tại wetland $\mathrm{A}$ cao hơn wetand $\mathrm{C}$. Trong đó, hiệu suất xử lý trung bình thấp nhất là $31 \%$ ứng với chùm ngây tại bể lọc thực vật $\mathrm{C}$, cao nhất là $41 \%$ ứng với chuối mỏ két tại bể lọc thực vật $\mathrm{A}$. Hiệu suất tháng đầu thấp do mô hình mới chạy các lớp vật liệu và hệ rễ của thực vật chưa ổn định, gây ảnh hưởng kết quả. Hiệu suất tăng dần qua các tháng trong tháng 11 có hiệu suất xử lý cao nhất.

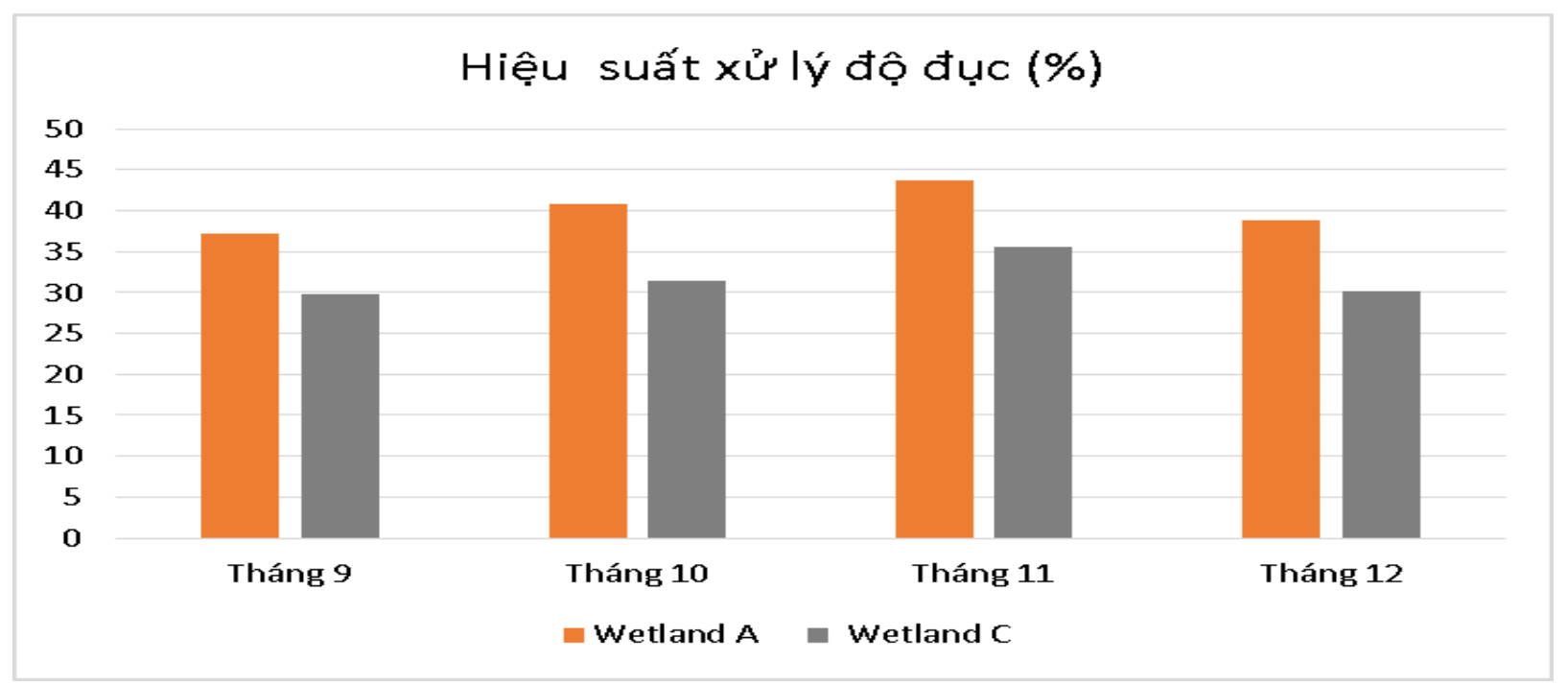

Hình 18. Hiệu suất xử lý độ đục trung bình qua 3 tháng nghiên cứu

Hiệu quả xử lý BOD, TSS, amoni, độ đục qua bống tháng thí nghiệm tại bể lọc thực vật $A$ và $C$ được sơ lược qua hai bảng sau: 


\section{Bảng 3}

Hiệu quả xử lý BOD, TSS, amoni, độ đục qua 4 tháng chạy sau xử lý bởi 2 hệ thống tại bể lọc thực vật $\mathrm{A}$

\begin{tabular}{|c|c|c|c|c|}
\hline \multirow{2}{*}{ Chỉ tiêu } & \multicolumn{4}{|c|}{ Trung bình hiệu suất } \\
\cline { 2 - 5 } & Tháng 9 & Tháng 10 & Tháng 11 & Tháng 12 \\
\hline BOD & $53 \%$ & $54 \%$ & $54 \%$ & $53 \%$ \\
\hline TSS & $54 \%$ & $56 \%$ & $71 \%$ & $64 \%$ \\
\hline Amoni & $51 \%$ & $55 \%$ & $58 \%$ & $54 \%$ \\
\hline Độ đục & $53 \%$ & $56 \%$ & $58 \%$ & $54 \%$ \\
\hline
\end{tabular}

Nguồn: Kết quả xử lý từ dữ liệu điều tra

\section{Bảng 4}

Hiệu quả xử lý BOD, TSS, Amoni, độ đục qua 4 tháng chạy sau xử lý bởi 2 hệ thống tại bể lọc thực vật $\mathrm{C}$

\begin{tabular}{|c|c|c|c|c|}
\hline \multirow{2}{*}{ Chỉ tiêu } & \multicolumn{4}{|c|}{ Trung bình hiệu suất } \\
\cline { 2 - 5 } & Tháng 9 & Tháng 10 & Tháng 11 & Tháng 12 \\
\hline BOD & $45 \%$ & $48 \%$ & $50 \%$ & $46 \%$ \\
\hline TSS & $47 \%$ & $48 \%$ & $64 \%$ & $60 \%$ \\
\hline Amoni & $45 \%$ & $48 \%$ & $50 \%$ & $50 \%$ \\
\hline Độ đục & $48 \%$ & $49 \%$ & $53 \%$ & $47 \%$ \\
\hline
\end{tabular}

Nguồn: Kết quả xử lý từ dữ liệu điều tra

\subsubsection{Khảo sát sinh trương - Phát triển của cây}

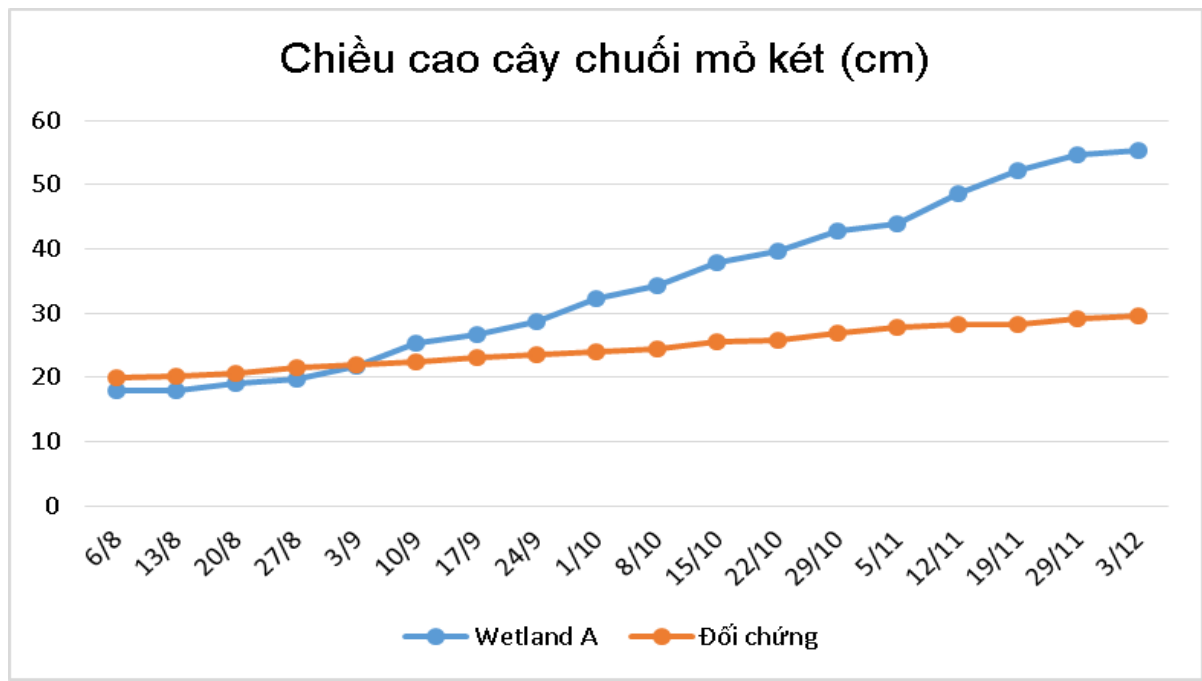

Hình 19. Đồ thị chiều cao cây chuối mỏ két ở bể lọc thực vật $\mathrm{A}$

Qua đồ thị chiều cao cây chuối mỏ két ở bể lọc thực vật $\mathrm{A}$, ta thấy chiều cao cây chuối mỏ két của 2 bể lọc thực vật trong giai đoạn thích nghi là thấp $(18-20 \mathrm{~cm})$, sau đó tiến hành 
chạy nước thải không liên tục tại tuần thứ 5 (ngày 3/9) chiều cao cây của bãi lọc thực vật A tăng dần qua các tuần. Chiều cao cây tăng vọt sau khi chạy nước thải liên tục tại tuần thứ 14 (ngày 5/11). So với cây chuối mỏ két tại bể đối chứng chạy bằng nước sạch, chiều cao cây cũng tăng, nhưng không đáng kể trong suốt quá trình làm thí nghiệm. Cây tại bể đối chứng tăng từ $19 \mathrm{~cm}$ lên $30 \mathrm{~cm}$, cây chỉ tăng $11 \mathrm{~cm}$ trong vòng 4 tháng. Còn cây tại bể lọc thực vật $\mathrm{A}$ chạy nước thải cây tăng từ $20 \mathrm{~cm}$ lên $55 \mathrm{~cm}$, cây đã tăng $35 \mathrm{~cm}$. Như vậy, cây đã hấp thụ các chất hữu cơ có trong nước thải và sinh trưởng, phát triển tốt hơn so với cây đối chứng 3,2 lần. Ở tuần thứ 13 (29/10) cây tại bể lọc thực vật A bắt đầu ra bông. Cây tại bể đối chứng tới tuần 17 (29/12) mới bắt đầu ra bông. Đến tuần 18 (3/12) các cây trong bể lọc thực vật $\mathrm{A}$ đã ra bông đồng loạt trong khi ở bể đối chứng thì tình trạng ra bông hầu như ngừng lại. Tại bể lọc thực vật $\mathrm{A}$ ban đầu với mật độ 9 cây trên 1 bể, sau khi kết thúc thí nghiêm mật độ cây trên bể tăng rất nhiều với 63 cây. Trong khi đó, tại bể đối chứng mật độ cây ban đầu là 3 cây và không tăng thêm trong suốt qua trình thí nghiệm.

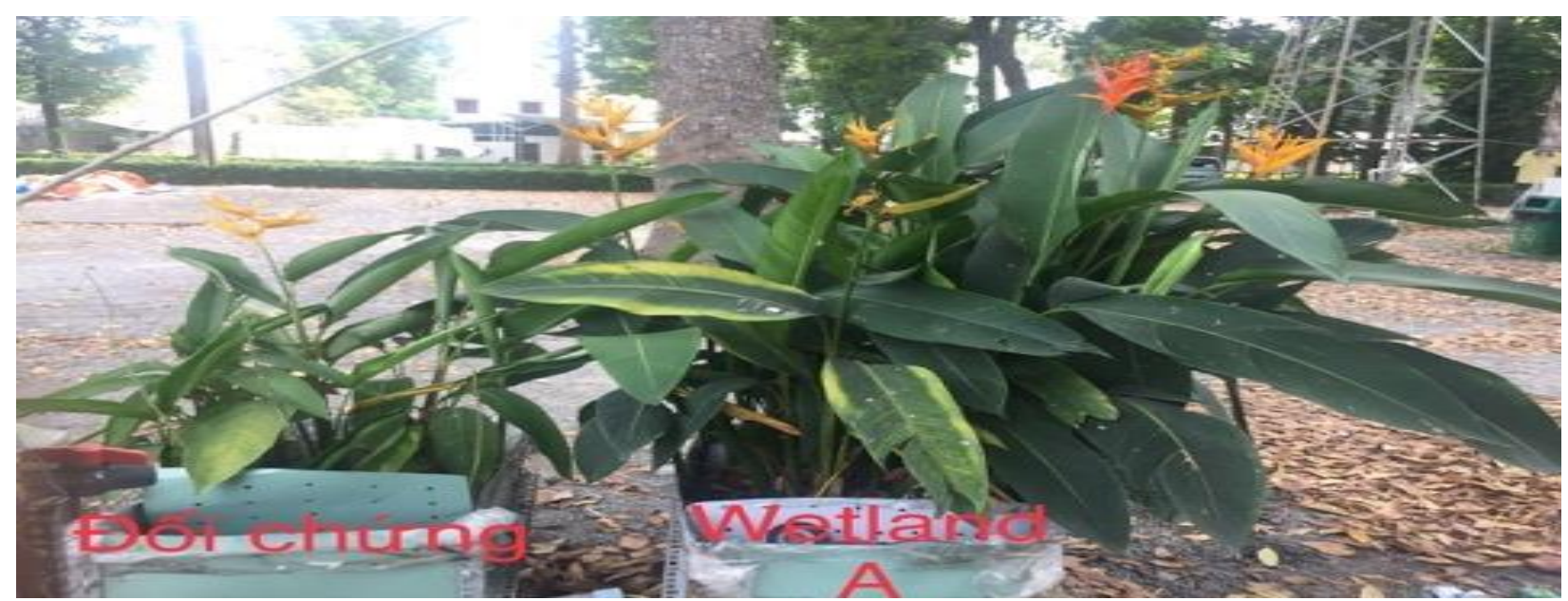

Hình 20. So sánh tình trạng ra bông giữa hai bể wetland $\mathrm{A}$ và đối chứng (cây chuối mỏ két tại bể wetland A ra bông rất nhiều so với bể đối chứng)

\section{Chiều cao cây chùm ngây $(\mathrm{cm})$}

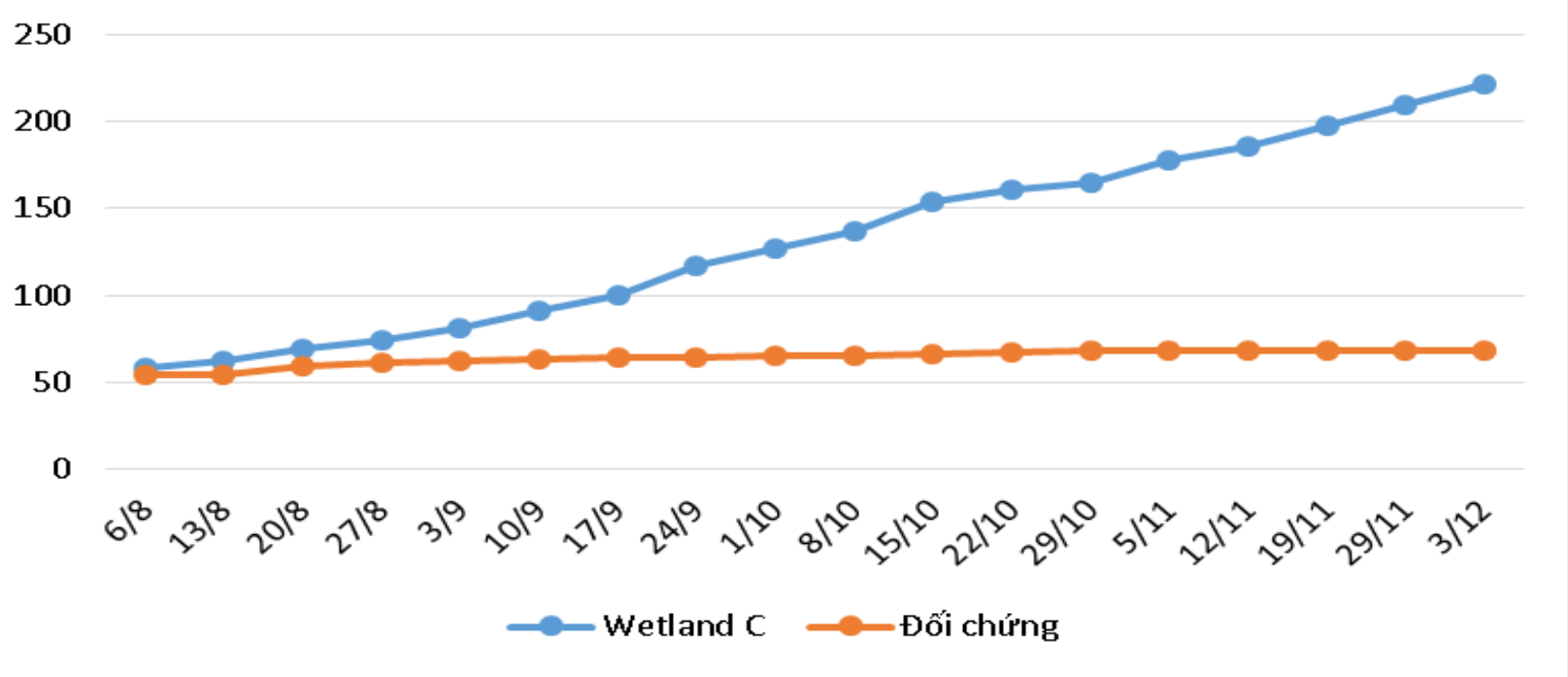

Hình 21. Đồ thị chiều cao cây chùm ngây ở bể lọc thực vật $\mathrm{C}$ 
Qua đồ thị ta thấy chiều cao cây chùm ngây của 2 bể lọc thực vật trong giai đoạn thích nghi là thấp $(50-55 \mathrm{~cm})$, sau đó tiến hành chạy nước thải không liên tục tại tuần thứ 5 (ngày 3/9) chiều cao cây của bãi lọc thực vật $C$ tăng dần qua các tuần. Chiều cao cây tăng nhiều sau khi chạy nước thải liên tục tại tuần thứ 14 (ngày $5 / 11$ ). So với cây chùm ngây tại bể đối chứng chạy bằng nước sạch, chiều cao cây cũng tăng, nhưng tăng rất ít trong suốt quá trình làm thí nghiệm. Cây chùm ngây tại bể chạy nước thải tăng từ $50 \mathrm{~cm}$ lên đến $225 \mathrm{~cm}$, cây tại bể đối chứng chỉ tăng từ $50 \mathrm{~cm}$ đến $55 \mathrm{~cm}$. Chiều cao cây tại bể lọc thực vật $\mathrm{C}$ tăng gấp 3,5 lần so với đối chứng. Trong những tuần chạy nước thải không liên tục cây chùm ngây tại bể lọc thực vật $\mathrm{C}$ phát triển tốt, khi chạy liên tục cây có dấu hiệu vàng lá, rụng lá nhưng không chết. Điều đó chứng tỏ cây chùm ngây có thể hấp thụ chất hữu cơ trong nước thải và phát triển tốt ở mức vừa phải. Khi nồng độ chất hữu cơ qua cao thì cây sẽ có hiện tượng vàng lá, rụng lá, cành có thể dẫn đến úng rễ và chết cây. Cây chùm ngây không phù hợp để xử lí nước thải có lưu lượng nước lớn. Dưới đây là hình cây chùm ngây trước và sau qua trình thí nghiệm.

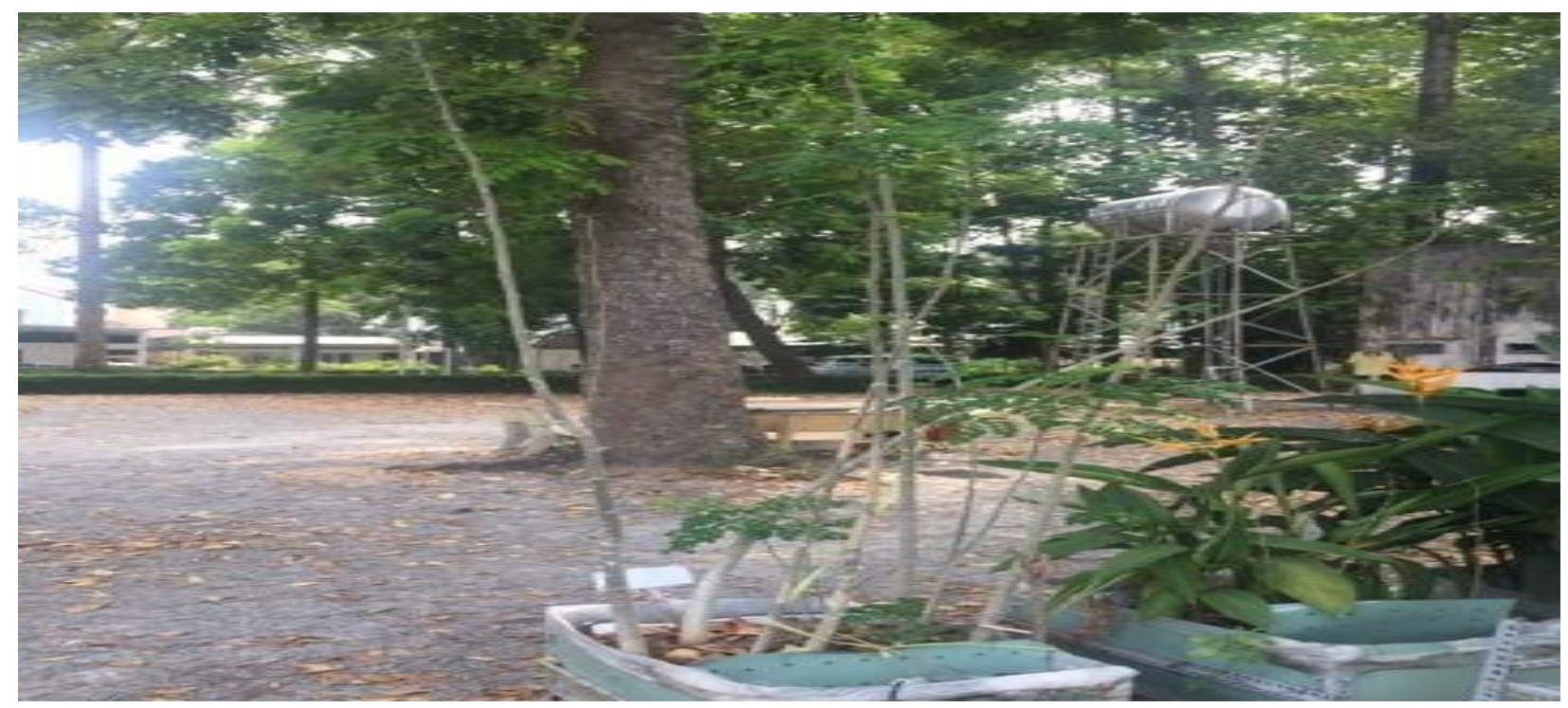

Hình 22. Cây chùm ngây khi kết thúc thí nghiệm

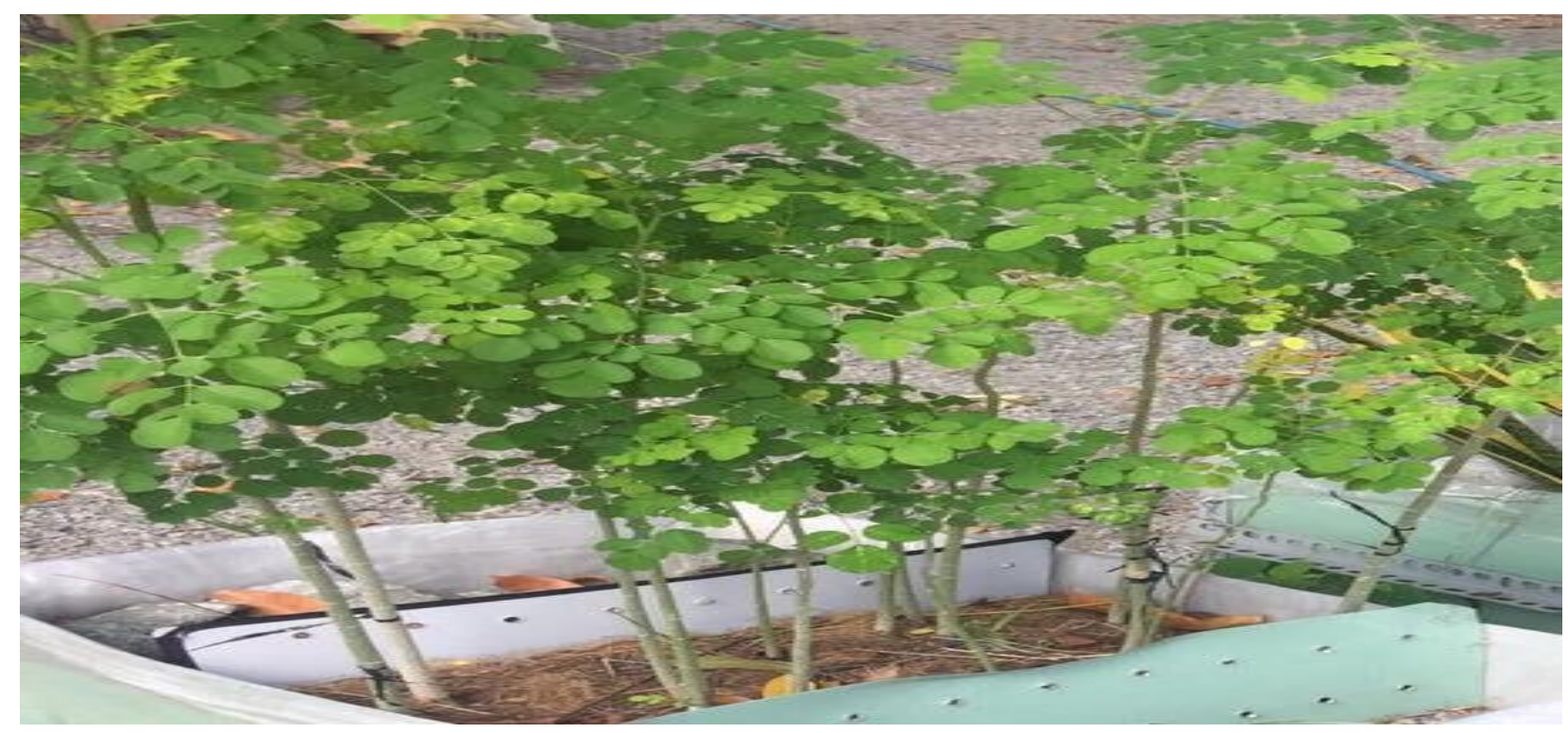

Hình 23. Cây chùm ngây trước khi thí nghiệm 


\section{Kết luận}

Trong nghiên cứu này, bể lọc sinh học được xem là một phương pháp để xử lý sơ bộ nước thải chăn nuôi heo sau Biogas kết hợp với bể lọc thực vật nhằm nâng cao hiệu quả chuyển hóa chất ô nhiễm bằng thực vật, thân thiện với môi trường. Nước thải chăn nuôi heo sau Biogas là nguồn nước thải có nồng độ ô nhiễm chất hữu cơ, rắn lơ lửng, amoni cao.

Trên cơ sở kết quả nghiên cứu đạt được rút ra các kết luận như sau:

• Đối với bể lọc sinh học

- Sau thời gian chạy hệ thống với nước thải giết mổ 3 tuần màng sinh học (biofim) hình thành và có thể xử lý nước thải chăn nuôi heo sau Biogas.

- Có thể sử dụng các vật liệu phổ biến và giá thành rẻ như giá thể nhựa bánh xe để làm vật liệu bám dính cho bể sinh học xử lý nước thải.

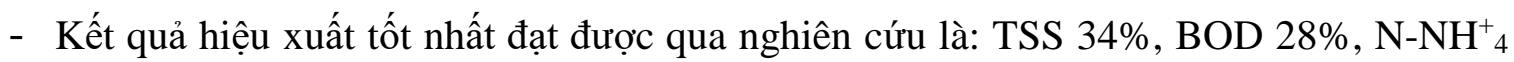
$29 \%$ và độ đục $26 \%$.

- Mặc dù hiệu xuất xử lý BOD, TSS, amoni, độ đục khá cao nhưng nước thải sau bể lọc sinh học vẫn chưa đạt giá trị tiêu chuẩn để có thể đưa ra môi trường.

- Nồng độ BOD, TSS, amoni, độ đục cao trong nước thải sau biogas là một thách thức lớn trong việc áp dụng hệ thống công nghệ xử lý phù hợp về kỹ thuật cũng như đảm bảo phù hợp thực tiễn quy mô hộ chăn nuôi nhỏ.

- Đối với bể lọc thực vật

- Sau giai đoạn thích nghi, chiều cao cây tại bể có nước thải chạy qua cao hơn so với bể đối chứng. Trong nước thải có các thành phần hữu cơ giúp cây sinh trưởng và phát triển tốt hơn và cây xử lý được các thành phần ô nhiễm trong nước. Theo kết quả nghiên cứu cây chuối mỏ két có tiềm năng xử lý nước thải tốt hơn cây chùm ngây.

- Thông qua việc đánh giá các chỉ tiêu BOD, TSS, amoni, độ đục thì trung bình hiệu quả xử lý của bể lọc thực vật chưa cao nhưng có những thời điểm giá trị đầu ra sau xử lý đã đạt tiêu chuẩn xả thải.

- Hiệu suất xử lý cao nhất của bể lọc thực vật A về BOD là $36 \%$, amoni là 41\%, TSS là $59 \%$, độ đục là $44 \%$.

- Hiệu suất xử lý cao nhất của bể lọc thực vật $\mathrm{C}$ về $\mathrm{BOD}$ là $30 \%$, amoni là $33 \%$, TSS là 48\%, độ đục là $36 \%$.

- Việc áp dụng bể lọc thực vật cho việc nâng cao hiệu quả xử lý nước thải sau biogas là thân thiện với môi trường, cần được nghiên cứu sâu hơn nữa để hoàn thiện công nghệ nhằm đảm bảo tiêu chuẩn xả thải.

\section{Tài liệu tham khảo}

Chăn Nuôi Việt Nam. (2018). Thống kê chăn nuôi Việt Nam 01/04/2018 về số luợng đầu con và sản phẩm gia súc, gia cầm [Vietnam livestock statistics April 1, 2018 on the number of heads and livestock and poultry products]. Retrieved December 17, 2019, from https://channuoivietnam.com/thong-ke-chan-nuoi/ 
Choi, E., \& Eum, Y. (2002). Strategy for nitrogen removal from piggery waste. Water Science and Technology, 46(6/7), 347-354. doi:10.2166/wst.2002.0699

Costerton, J. W., Lewandowski, Z., Caldwell, D. E., Korber, D. R., \& Lappin-Scottb, H. M. (1995). Microbial biofilms. Annual Review of Microbiology, 49, 711-745. doi:10.1146/annurev.mi.49.100195.003431

Grady, C. P. L., Jr., Daigger, G. T., \& Lim, H. C. (1999). Biological wastewater treatment: Second edition. New York, NY: Marcel Dekker, Inc.

Le, C. N. P., Le, T. C. H., \& Nguyen, H. T. L. (2012). Xử lý ammonium trong nước thải giết mổ bằng việc kết hợp quá trình nitrit hóa một phần/anammox [Ammonium treatment in slaughter wastewater by incorporating partial nitrification/anammox]. Tạp chí Sinh học, 34(3se), 105-110.

Luong, D. P., (2007). Công nghệ xủ lý nước thải bằng biện pháp sinh hoc. Hanoi, Vietnam: NXB Giáo Dục Việt Nam.

Mai, T. T. T., Pham, N. D., \& Tran, T.H., (2019). Nghiên cứu đánh giá khả năng xử lí nước thải giết mổ bằng bể phản ứng sinh học giá thể cố định [Researching and evaluating the ability of the slaughter wastewater's treatment with a fixed media bioreactor]. Tap chí Khoa hoc Đại học Mở Thành phố Hồ Chí Minh, 14(2), 72-81.

Nguyen, T. H. (2017). Thực trạng xử lý môi trường chăn nuôi tại Việt Nam và đề xuất giải pháp quản lý [Current situation of livestock environment treatment in Vietnam and proposed management solutions]. Tạp chí môi trường, 6, 12-15.

Nguyen, V. T. (1998). Bước đầu nghiên cúu sủ dụng chitosan vào quá trình keo tụ để xủ lý nước thái [Initial research on using chitosan in the flocculation process for wastewater treatment] (Bachelor's thesis). Trường Đại học Khoa học - Đại học Huế, Huế.

Nguyen, V. P. (2010). Giáo trình Xủ lý nước thải sinh hoạt và công nghiệp bằng phuơng pháp sinh hoat [Curriculum for domestic and industrial wastewater treatment by living method]. Hanoi, Vietnam: NXB Xây dựng.

Park, J. Y., \& Yoo, Y. J. (2009). Biological nitrate removal in industrial wastewater treatment: Which electron donor we can choose. Applied Microbiology and Biotechnology, 82(3), 415-429. doi:10.1007/s00253-008-1799-1

Tchobanoglous, G., Burton, F. L., \& Stensel, H. D. (2016). Wastewater engineering - Treatment and reuse (4th ed.). New York, NY: Metcalf \& Eddy, Inc.

Thai, V. A., \& Le, T.C.C. (2016). Nghiên cứu khả năng xử lý nước thải sinh hoạt bằng mô hình đất ngập nước nhân tạo dùng sậy, nến, vertiver [Research on the possibility of treating domestic wastewater with an artificial wetland model using reeds, candles and vertiver]. Chuyên san khoa hoc Đại họ Cần Tho, 15, 53-60.

Trinh, X. L. (2009). Tính toán thiết kế các công trình xủ lý nước thải [Calculation and design of wastewater treatment facilities]. Hanoi, Vietnam: NXB Xây dựng. 